ZOOLOGIA 31 (2): 126-146, April, 2014

http://dx.doi.org/10.1590/S1984-46702014000200004

\title{
Herpetofauna of Paranapiacaba: expanding our knowledge on a historical region in the Atlantic forest of southeastern Brazil
}

\author{
Vivian Trevine' ${ }^{1}$ Maurício C. Forlani ${ }^{1}$, Célio F. B. Haddad ${ }^{2} \&$ Hussam Zaher $^{1,3}$
}

\author{
${ }^{1}$ Museu de Zoologia, Universidade de São Paulo. Avenida Nazaré 481, 04263-000 São Paulo, SP, Brazil. \\ ${ }^{2}$ Departamento de Zoologia, Instituto de Biociências, Universidade Estadual Paulista. Avenida 24-A, 1515, Bela Vista, \\ 13506-900 Rio Claro, SP, Brazil. \\ ${ }^{3}$ Correspondig author. Email: hussam.zaher@gmail.com
}

\begin{abstract}
The largest area of preserved Atlantic forest is located in the southern portion of Brazil. The region of Paranapiacaba is depicted in Brazilian zoological studies as one of the first and most intensely sampled areas of the state of São Paulo.We provide a concise list of reptiles and amphibians from the Paranapiacaba Municipal Park. It represents the first comprehensive survey of the group in the area. We recorded 136 species of reptiles and amphibians from field surveys, museum collections and the literature. The anuran diversity of Paranapiacaba is greater than that of Estação Ecológica de Boracéia, which has been considered the most distinctive areas in São Paulo in terms of amphibian diversity. The rich history of herpetological research in the region, including the occurrence of the two most threatened species in Brazil, converts the area to an important conservation landmark for the Brazilian herpetofauna.
\end{abstract}

KEY WORDS. Anuran conservation; conservation unit; herpetofaunal diversity; historical records; São Paulo state.

The Atlantic Forest Domain (sensu AB'SABER 2003) is formed by a mosaic of environments within several biogeographic subunits (CÂmara 2003, Silva \& Casteleti 2005, Carnaval et al. 2009). It exhibits great latitudinal, altitudinal and longitudinal variation, featuring a unique diversity of flora and fauna, and high levels of endemism (Myers et al. 2000, Laurance 2009, Ribeiro et al. 2011). The Atlantic Forest now is $11.7 \%$ of its original extension, and more than half of its remnants are restricted to the Serra do Mar formation, in the states of São Paulo and Paraná (Galindo-Leal \& CÂmara 2005, Ribeiro et al. 2009).

The herpetofauna of the state of São Paulo is extremely diverse, representing approximately $30 \%$ of all Brazilian diversity (Rossa-Feres et al. 2011, ZAHer et al. 2011). The amphibian fauna of the Serra do Mar, Serra da Mantiqueira and Serra de Paranapiacaba is clearly the richest of the state (GARCIA et al. 2009a). Moreover, most of the Squamata reptiles of São Paulo are endemic to elevated areas within the Serra do Mar range (Marques et al. 2004, Rodrigues 2005, Rossa-Feres et al. 2008).

The geomorphological formation knwon as "Serra de Paranapiacaba" encompasses an interiorized portion of the Serra do Mar, and part of the Atlantic plateau along the southern portion of the state of São Paulo (Guix et al. 2000, Cruz \& FeIo 2007). The district known as "Alto da Serra", "Alto da Serra de Paranapiacaba", "Alto da Serra de Cubatão", or simply as "Paranapiacaba," is located at the edge of the Atlantic Plateau between the metropolitan area of São Paulo and its coast,and it is part of the Serra de Paranapiacaba (Bokermann 1966). This district was founded in the nineteenth century, along with the construction of the first railroad of the state (Santos-Jundiai railway) (Lopes \& KIRIZAWA 2009). The region was also the setting point of one of the first conservation units of Brazil, the Reserva Biológica do Alto da Serra de Paranapiacaba (REBIO) (LOPES \& KiRIZAWA 2009).

Since its foundation, several scientific expeditions have visited Paranapiacaba, which was one of the first locations in São Paulo to be surveyed by zoologists. Several notable scientists explored the area, such as the naturalists Frederico Carlos Hoehne, Hermann Friedrich von Ihering, Jean Massart, Carl Friedrich Von Martius, Auguste de Saint-Hilaire, Arthur Neiva, Affonso de E. Taunay, Hermann Luederwaldt, and the herpetologists Alípio de Miranda-Ribeiro, Adolpho Lutz, Bertha Lutz, Joaquim Venâncio, Oswaldo Peixoto, and Werner Bokermann (Melo et al. 2009, Verdade et al. 2009).

Although Paranapiacaba still represents one of the most intensively surveyed localities of the state of São Paulo, being especially relevant for anurans (Dixo \& Verdade 2006), its herpetofauna remains poorly known. Additionally, only a small fraction of the information available in scientific collections, and which deals with specific aspects of the anuran community, has been published (e.g., Bokermann 1968, Sazima \& Bokermann 1978, Pombal \& Cruz 1999, Patto \& Pie 2001, Oliveira et al. 2008, PMSA 2008, VERDADE et al. 2009).

Here, we provide a concise list of the reptiles and amphibians from the Parque Natural Municipal Nascentes de Paranapiacaba. Our study represents the first comprehensive herpetofaunal survey for the region. 


\section{MATERIAL AND METHODS}

The present work was conducted at the Parque Natural Municipal Nascentes de Paranapiacaba (PNMNP), municipality of Santo André. The park occupies 426 ha of mountainous Atlantic Forest formation, between $23^{\circ} 47^{\prime} 4.9^{\prime \prime} \mathrm{S}-23^{\circ} 45^{\prime} 27.9^{\prime \prime} \mathrm{S}$ and $46^{\circ} 18^{\prime} 19.4^{\prime \prime} \mathrm{W}-46^{\circ} 17^{\prime} 7.8^{\prime \prime} \mathrm{W}$, at an altitude range of 850 to approximately $1174 \mathrm{~m}$ (PMSA 2008). The park surrounds the Paranapiacaba district, adjoining the REBIO, and also the locality known as Campo Grande da Serra, which corresponds to the deactivated Campo Grande train station (BoKermanN 1966). It is also contiguous with the Parque Estadual da Serra do Mar, and is located at the end of the Mogi river valley (Fig. 1). Historical factors, for instance extraction of natural resources for railroad maintenance and for the construction of the village of Paranapiacaba, led to a predominantly altered vegetational landscape.

The climate of the PNMNP is classified as altitudinal tropical and mesothermic super humid. Mean annual temperatures vary little, ranging from $14^{\circ}$ or $15^{\circ} \mathrm{C}$ to $21^{\circ}$ or $22^{\circ} \mathrm{C}$. The region is within the greatest cell of precipitation in Brazil $(3,300 \mathrm{~mm}$ mean average). There is no hydric deficit in the PNMNP, and humidity is high throughout the year. The high humidity, combined with the orographic effect coming from the Serra do Mar, produce a fog that is distinctive (GUTJAHR \& TAVARES 2009).

We conducted 15 field surveys, from November 2009 to March 2011. Regular sampling lasted eight to 10 days each month, totaling 117 sampling days. Three complementary methods were used: visual surveys (CRUMP \& SCOTT 1994), pitfall traps with drift-fences (Gibions \& Semlitsch 1982, CoRn 1994, Cechin \& Martins 2000, Blomberg \& Shine 2006), and occasional encounters (CAmpbell \& Christman 1982, SAWAYA et al. 2008).

Three sets of pitfall traps were used. Each was composed of two stations with ten 100-liter plastic recipients, totaling 60 recipients installed. Every recipient was connected to another by eight $\mathrm{m}$ of drift-fences. The fences were $1 \mathrm{~m}$ high, and were buried approximately $20 \mathrm{~cm}$ into the ground, passing through the center of each recipient. The pitfall sites were located at least $300 \mathrm{~m}$ apart from each other, in order to maintain the spatial independence of the sample units. The sites were selected as to encompass different variables, such as arboreal physiognomy and the influence of water bodies. Pitfall traps were inspected daily totaling 111 days of opened traps (6,600 recipients-days).

In addition to pitfall traps, visual and audio surveys were performed at eight different sites within the PNMNP and also in adjacent areas. Sampling was carried out preferentially during the evening and at night, by a team of two to four researchers. Anuran vocalization was also registered with a portable digital recorder (Sony ICD-P630F) to assist species identification.

Data collected by other means than the methods mentioned above were classified as occasional encounters, and pertain exclusively to random species records. Hence, this sample effort was not considered for data analysis. We collected the following information for each specimen registered by us: location, method of collection, date and time of collection, type of environment, activity patterns, and approximate climate conditions. All specimens collected were deposited in the Coleção Célio F.B. Haddad, Universidade Estadual Paulista "Júlio de Mesquita Filho", Rio Claro, São Paulo (amphibians) and Coleção Herpetológica do Museu de Zoologia da Universidade de São Paulo, São Paulo (amphibians and reptiles).

Secondary data was retrieved from the literature and the examination of specimens from Santo André and adjoining municipalities (Santos, Cubatão, Mogi das Cruzes, Rio Grande da Serra and Suzano), deposited in the following herpetological collections: Coleção Célio F. B. Haddad, Universidade Estadual Paulista "Júlio de Mesquita Filho", Rio Claro, São Paulo (CFBH), Coleção Herpetológica "Alphonse Richard Hoge", Instituto Butantan, São Paulo (IB), Coleção Herpetológica do Museu de Zoologia da Universidade de São Paulo, São Paulo (MZUSP), and Museu de História Natural da Universidade Estadual de Campinas, São Paulo (ZUEC). Specimens from the collection of the Instituto Butantan were only considered when their identification was confirmed by one of us, prior to the 2010 fire (KuMAR 2010).

We adopted the taxonomic classification of Frost et al. (2001), Kearney (2003), Zaher et al. (2009), and Carrasco et al. (2012) for reptiles, with one exception: species of Liophis Wagler, 1830 were allocated to Erythrolamprus Boie, 1826 (Curcio et al. 2009, Forlani et al. 2010, Grazziotin et al., 2012). The classification of amphibians follows Frost (2013) and Caramaschi \& Cruz (2013).

We used the sampling data to analyze species composition and richness (number of species). Relative abundance was estimated as a percentage of the number of individuals from each species over the total number of individuals registered. Relative abundance was calculated exclusively based on data collected by pitfall traps. Efficiency of the sampling method was evaluated using species rarefaction curves (Colwell \& Coddington 1994, Gotelui \& Colwell 2001, Thompson et al. 2003), with 95\% confidence interval and 1000 aleatorizations, using the software EstimateS 8.20 (Colwell 2009). Richness was assessed through a non-parametric first order Jackknife index (Heltsche \& Forrester 1983, Hellmann \& Fowler 1999). Sample effort was considered as the number of open pitfall traps per sampling day. Specimens collected outside the sampling period were not considered in the analysis.

In order to define patterns of species distribution in Paranapiacaba, we allocated each taxon into one of the following five categories: 1) species distribution restricted to the Paranapiacaba region, also encompassing the Estação Ecológica

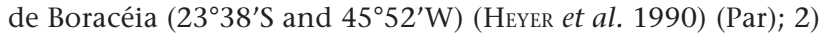
species endemic to the Serra do Mar range within the state of São Paulo (S); 3) species distributed in the entire Serra do Mar 

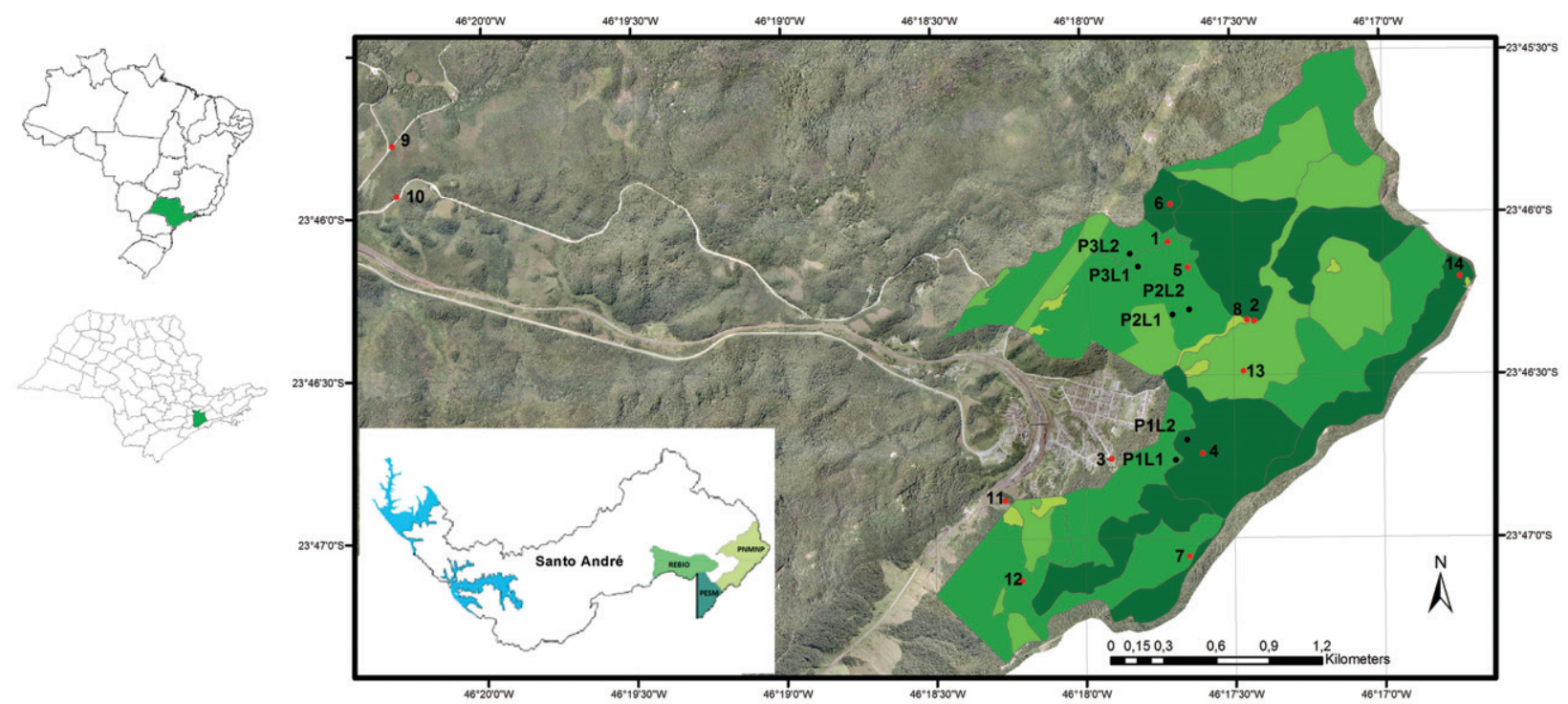

Figure 1. Geographic position of the study area within the state of São Paulo and the municipality of Santo André, including adjacent conservation units. PNMNP: Parque Natural Municipal Nascentes de Paranapiacaba, PESM: Parque Estadual da Serra do Mar, REBIO: Reserva Biológica do Alto da Serra de Paranapiacaba (Adapted from PMSA 2008). Red dots, numbered from 1 to 13 , represent localities of visual survey samples, black dots represent localities of pitfall trap samples (P1, P2 and P3).

formation, from south to southeastern Brazil (Se); 4) species broadly distributed within the Atlantic forest (southeastern, northeastern and/or southern Brazil) (Af); 5) species broadly distributed in Brazil, with records outside the Atlantic Forest Domain (Br).

\section{RESULTS}

\section{Amphibians}

We recorded a total of 80 species of anurans for the PNMNP and Paranapiacaba region, Santo André municipality. Fifty-six species of anurans were catalogued as a result of the field survey, and secondary data (see methods) yielded 73 records. New distributional records for 15 species, including four undescribed species (Table I), resulted for the region. Ten families were registered: Brachycephalidae (11 species), Bufonidae (4), Centrolenidae (1) Craugastoridae (2), Cycloramphidae (5), Hemiphractidae (3), Hylidae (34), Hylodidae (6), Leptodactylidae (13), and Odontophrynidae (1) (Figs 2-61).

Most species are distributed on mountainous areas of the Atlantic forest from south and southeastern Brazil (60.5\%). Eight of those are strictly endemic to the Paranapiacaba region (10.5\%) and 14 (18.4\%) are endemic to the Serra do Mar formation of the state of São Paulo. The remaining species are broadly distributed throughout the Atlantic Forest (23.7\%), and $15.8 \%$ of the registred anurans occur in more than one biome within Brazil (Table I).
Considering data from pitfall traps alone, we captured 811 specimens from 17 anuran species. The dominant species was Ischnocnema parva (314 individuals, 38.7\%), followed by another brachycephalid, I. guentheri (154 individuals, 18.9\%), and by Physalaemus moreirae (152 individuals, 18.7\%). Eight species exhibited intermediary abundance: Leptodactylus ajurauana (33 individuals, $4.1 \%$ ), L. cf. marmoratus (31 individuals, 3.8\%), Haddadus binotatus (26 individuals, 3.2\%), Rhinella icterica (19 individuals, $2.3 \%)$, R. ornata (18 individuals, 2.2\%), Brachycephalus sp. (14 individuals, 1.7\%), Ischnocnema sp (gr. lactea) (13 individuals, 1.6\%), and Paratelmatobius cardosoi (10 individuals, $1.2 \%)$. Six other species were considered rare, comprising less than $1 \%$ of the total records: Bokermannohyla hylax (seven specimens), Dendrophryniscus brevipollicatus (seven), Cycloramphus eleutherodactylus (five), Ichnocnema cf. spanios (four), I. hoehnei (two) and I. juipoca (two).

Species rarefaction curves from pitfall traps data stabilized for sampled amphibians (Fig. 62). The jackknife index calculated for anurans (Jack1 = $17 \pm 0$ ) corresponded fairly to the number of observed species.

\section{Reptiles}

We recorded fifty six species of reptiles for the PNMNP and the Paranapiacaba region (Table II). Of these, 39 were snakes classified in four families: Colubridae (six species), Dipsadidae (30), Elapidae (one), Viperidae (one), and Tropidophiidae (one); and 13 were lizards from five families: Anguidae (two species), Gekkonidae (one species), Gymnophtalmidae (five), Leiosauridae 
Table I. Species composition of anurans from Parque Municipal Nascentes de Paranapicaba (PNMNP), Santo André, São Paulo. Type of data collected: 1 . Primary data from field surveys during the study period; 2 . secondary data gathered from herpetological collection catalogs, 3. secondary data from Verdade et al. (2009). Localities of occurrence at site areas: a. Paranapiacaba or Alto da Serra, b. PNMNP (study area), c: Reserva Biológica do Alto da Serra de Paranapicaba, d: Campo Grande da Serra, e: Santo André municipality. Geographical distribution: Par: species exclusive to Paranapiacaba region, S: endemic for the Serra do Mar from São Paulo state, Se: Serra do Mar formation, south and southeastern Brazil, Af: broad distribution within the Atlantic forest, Br: broad distribution in Brazil. * Represents "Paranapiacaba" or "Alto da Serra" as type locality; ${ }^{* \star}$ Paranapiacaba as type locality of one of the species synonyms; ${ }^{* \star *}$ Campo Grande as type locality.

\begin{tabular}{|c|c|c|c|c|}
\hline Family & Species & Data & Site & Distribution \\
\hline \multirow[t]{11}{*}{ Brachycephalidae } & Brachycephalus sp. & 1,2 & $\mathrm{~b}, \mathrm{c}$ & Par \\
\hline & Brachycephalus hermogenesi (Giaretta \& Sawaya, 1998) & 3 & $b, c$ & $\mathrm{Se}$ \\
\hline & Ischnocnema cf. spanios (Heyer, 1985) & 1 & $b, e$ & Par \\
\hline & Ischnocnema gerhti (Miranda-Ribeiro, 1926) & 2,3 & a & Par \\
\hline & Ischnocnema guentheri (Steindachner, 1864) & $1,2,3$ & $a, b, c, e$ & Af \\
\hline & Ischnocnema hoehnei* (Lutz, 1958) & $1,2,3$ & $a, b$ & $\mathrm{Se}$ \\
\hline & Ischnocnema juipoca (Sazima \& Cardoso, 1978) & 1,3 & $\mathrm{~b}$ & $\mathrm{Br}$ \\
\hline & Ischnocnema nigriventris*(Lutz, 1958) & 1,3 & $a, b$ & Par \\
\hline & Ischnocnema parva (Girard, 1853) & $1,2,3$ & $a, b, c$ & $\mathrm{Se}$ \\
\hline & Ischnocnema sp. (aff. guentheri) & 1 & b & - \\
\hline & Ischnocnema sp. (lactea series) & 1 & $\mathrm{~b}$ & - \\
\hline \multirow[t]{4}{*}{ Bufonidae } & Dendrophryniscus brevipollicatus** Jiménez de la Espada, 1870 & $1,2,3$ & $a, b, c$ & $\mathrm{Se}$ \\
\hline & Dendrophryniscus cf. brevipollicatus & 1,2 & $a, b, c$ & - \\
\hline & Rhinella icterica (Spix, 1824) & $1,2,3$ & $a, b, c, e$ & Af \\
\hline & Rhinella ornata (Spix, 1824) & $1,2,3$ & $a, b, c, e$ & Af \\
\hline Centrolenidae & Vitreorana uranoscopa (Müller, 1924) & $1,2,3$ & $a, b$ & Af \\
\hline \multirow[t]{2}{*}{ Craugastoridae } & Haddadus binotatus (Spix, 1824) & $1,2,3$ & $a, b, c$ & Af \\
\hline & Holoaden suarezi Martins \& Zaher, 2013 & 2 & a & S \\
\hline \multirow[t]{5}{*}{ Cycloramphidae } & Cycloramphus acangatan Verdade \& Rodrigues, 2003 & 2,3 & $a, b, c$ & s \\
\hline & Cycloramphus dubius* (Miranda-Ribeiro, 1920) & 2,3 & $a, b$ & S \\
\hline & Cycloramphus eleutherodactylus* (Miranda-Ribeiro, 1920) & $1,2,3$ & $a, b, c$ & $\mathrm{Se}$ \\
\hline & Cycloramphus semipalmatus* (Miranda-Ribeiro, 1920) & 2,3 & $a, b$ & S \\
\hline & Thoropa taophora*(Miranda-Ribeiro, 1923) & $1,2,3$ & a & S \\
\hline \multirow[t]{3}{*}{ Hemiphractidae } & Fritziana fissilis (Miranda-Ribeiro, 1920) & $1,2,3$ & $a, b, c$ & $\mathrm{Se}$ \\
\hline & Fritziana ohausi (Wandolleck, 1907) & $1,2,3$ & $a, b$ & $\mathrm{Se}$ \\
\hline & Gastrotheca fulvorufa*(Andersson, 1911) & 1,2 & $a, b$ & $\mathrm{Se}$ \\
\hline \multirow[t]{14}{*}{ Hylidae } & Aplastodiscus albosignatus* (Lutz and Lutz, 1938) & $1,2,3$ & $a, b, c$ & Af \\
\hline & Aplastodiscus arildae (Cruz \& Peixoto, 1985) & 1,2 & $a, b$ & $\mathrm{Se}$ \\
\hline & Aplastodicus leucopygius (Cruz \& Peixoto, 1985) & $1,2,3$ & $a, b, c, e$ & $\mathrm{Se}$ \\
\hline & Bokermannohyla astartea* Bokermann, 1967 & 2,3 & $a, d$ & $S$ \\
\hline & Bokermannohyla circumdata (Cope, 1871) & $1,2,3$ & $a, b, c$ & Af \\
\hline & Bokermannohyla hylax (Heyer, 1985) & $1,2,3$ & $a, b, c, e$ & Af \\
\hline & Dendropsophus berthalutzae* (Bokermann, 1962) & $1,2,3$ & $a, b, c, d$ & Af \\
\hline & Dendropsophus elegans (Wied-Neuwied, 1824) & 1 & $\mathrm{~b}$ & Af \\
\hline & Dendropsophus microps (Peters, 1872) & $1,2,3$ & $a, b, d$ & Af \\
\hline & Dendropsophus minutus (Peters, 1872) & $1,2,3$ & $a, b, c, d$ & $\mathrm{Br}$ \\
\hline & Dendropsophus nanus (Boulenger, 1889) & 2 & d & $\mathrm{Br}$ \\
\hline & Dendropsophus sanborni (Schimdt, 1944) & 2,3 & $d$ & $\mathrm{Br}$ \\
\hline & Hypsiboas albomarginatus (Spix, 1824) & $1,2,3$ & $a, b, d$ & Af \\
\hline & Hypsiboas albopunctatus (Spix, 1824) & 2,3 & $a, d$ & $\mathrm{Br}$ \\
\hline
\end{tabular}


Table I. Continued.

\begin{tabular}{|c|c|c|c|c|}
\hline Family & Species & Data & Site & Distribution \\
\hline & Hypsiboas bandeirantes Caramaschi \& Cruz, 2013 & $1,2,3$ & $a, b, d$ & $\mathrm{Se}$ \\
\hline & Hypsiboas bischoffi (Boulenger, 1887) & $1,2,3$ & $a, b, c, d, c$ & Af \\
\hline & Hypsiboas cymbalum* (Bokermann, 1963) & 2,3 & $d$ & Par \\
\hline & Hypsiboas faber (Wied-Neuwied, 1821) & $1,2,3$ & $b, c$ & Af \\
\hline & Hypsiboas pardalis Spix, 1824 & $1,2,3$ & $b, d$ & $\mathrm{Se}$ \\
\hline & Phrynomedusa appendiculata (Lutz, 1925) & 2 & a & $\mathrm{Se}$ \\
\hline & Phrynomedusa fimbriata* Miranda-Ribeiro, 1923 & 2,3 & a & Par \\
\hline & Phyllomedusa burmeisteri Boulenger, 1882 & 2,3 & a & Af \\
\hline & Phyllomedusa rohdei Mertens, 1926 & 2 & $d$ & $\mathrm{Se}$ \\
\hline & Scinax alter (Lutz, 1973) & 2,3 & a & Af \\
\hline & Scinax berthae (Barrio, 1962) & 2,3 & $d$ & $\mathrm{Br}$ \\
\hline & Scinax cf. perpusillus Lutz \& Lutz, 1939 & $1,2,3$ & $a, b, c$ & Se \\
\hline & Scinax crospedospilus (Lutz, 1925) & $1,2,3$ & $a, b, c$ & $\mathrm{Se}$ \\
\hline & Scinax fuscovarius (Lutz, 1925) & $1,2,3$ & $a, b, c, d, e$ & $\mathrm{Br}$ \\
\hline & Scinax hayii (Barbour, 1909) & $1,2,3$ & $a, b, c, d, e$ & Se \\
\hline & Scinax hiemalis (Haddad \& Pombal, 1987) & 1,2 & $a, b, e$ & $S$ \\
\hline & Scinax rizibilis* (Bokermann, 1964) & $1,2,3$ & $b, d$ & Af \\
\hline & Scinax squalirostris (Lutz, 1925) & 2 & d & $\mathrm{Br}$ \\
\hline \multirow[t]{5}{*}{ Hylodidae } & Crossodactylus dispar Lutz, 1925 & 2,3 & c & $S$ \\
\hline & Crossodactylus gaudichaudii** Duméril \& Bibron, 1841 & 2,3 & $c, d$ & $\mathrm{Se}$ \\
\hline & Hylodes asper (Müller, 1924) & $1,2,3$ & $a, b$ & Se \\
\hline & Hylodes sp. (aff. phyllodes) & 1 & $\mathrm{~b}$ & - \\
\hline & Hylodes phyllodes Heyer \& Cocroft, 1986 & 2,3 & a & $S$ \\
\hline \multirow[t]{13}{*}{ Leptodactylidae } & Physalaemus bokermanni*** Cardoso \& Haddad, 1985 & $1,2,3$ & $a, d$ & $S$ \\
\hline & Physalaemus cuvieri Fitzinger, 1826 & $1,2,3$ & $a, b, d$ & $\mathrm{Br}$ \\
\hline & Physalaemus maculiventris* (Lutz, 1925) & 2,3 & $a, b$ & Af \\
\hline & Physalaemus moreirae*(Miranda-Ribeiro, 1937) & $1,2,3$ & $a, b, c$ & $S$ \\
\hline & Physalaemus olfersii (Lichtenstein \& Martens, 1856) & 2,3 & $a, c, d$ & Se \\
\hline & Leptodactylus ajurauna Berneck, Costa \& Garcia, 2008 & 1,2 & $a, b$ & $S$ \\
\hline & Leptodactylus cf. marmoratus (Steindachner, 1867) & $1,2,3$ & $a, b, c, e$ & Af \\
\hline & Leptodactylus flavopictus Lutz, 1926 & 2,3 & $a, b$ & Af \\
\hline & Leptodactylus furnarius* Sazima \& Bokermann, 1978 & 2,3 & $a, d$ & $\mathrm{Br}$ \\
\hline & Leptodactylus jolyi* Sazima \& Bokermann, 1978 & $1,2,3$ & $b, d$ & $\mathrm{Br}$ \\
\hline & Leptodactylus latrans (Steffen, 1815) & $1,2,3$ & $a, b, c, d$ & $\mathrm{Br}$ \\
\hline & Paratelmatobius cardosoi* Pombal \& Haddad, 1999 & $1,2,3$ & $a, b$ & Par \\
\hline & Paratelmatobius poecilogaster* Giaretta \& Castanho, 1990 & $1,2,3$ & $a, b$ & $S$ \\
\hline Odontophrynidae & Proceratophrys melanopogon*(Miranda-Ribeiro, 1926) & $1,2,3$ & $a, b, d$ & $\mathrm{Se}$ \\
\hline
\end{tabular}

(four), and Teiidae (one). There were also two amphisbaenids; and two chelonians (Figs 63-86). Secondary data was responsible for 29 records. Field surveys encountered 18 snakes, 10 lizards and two chelonians, seven of which represent new records for the area according to collection records (see MARQUes 2009) (Table II).
A significant proportion of reptile species were broadly distributed throughout the Atlantic Forest Domain (41.1\%). One snake is endemic to São Paulo (Atractus serranus) and 10.7\% of the species are restricted to the Serra do Mar formation of southeastern Brazil. Most reptile species recorded in this study, 

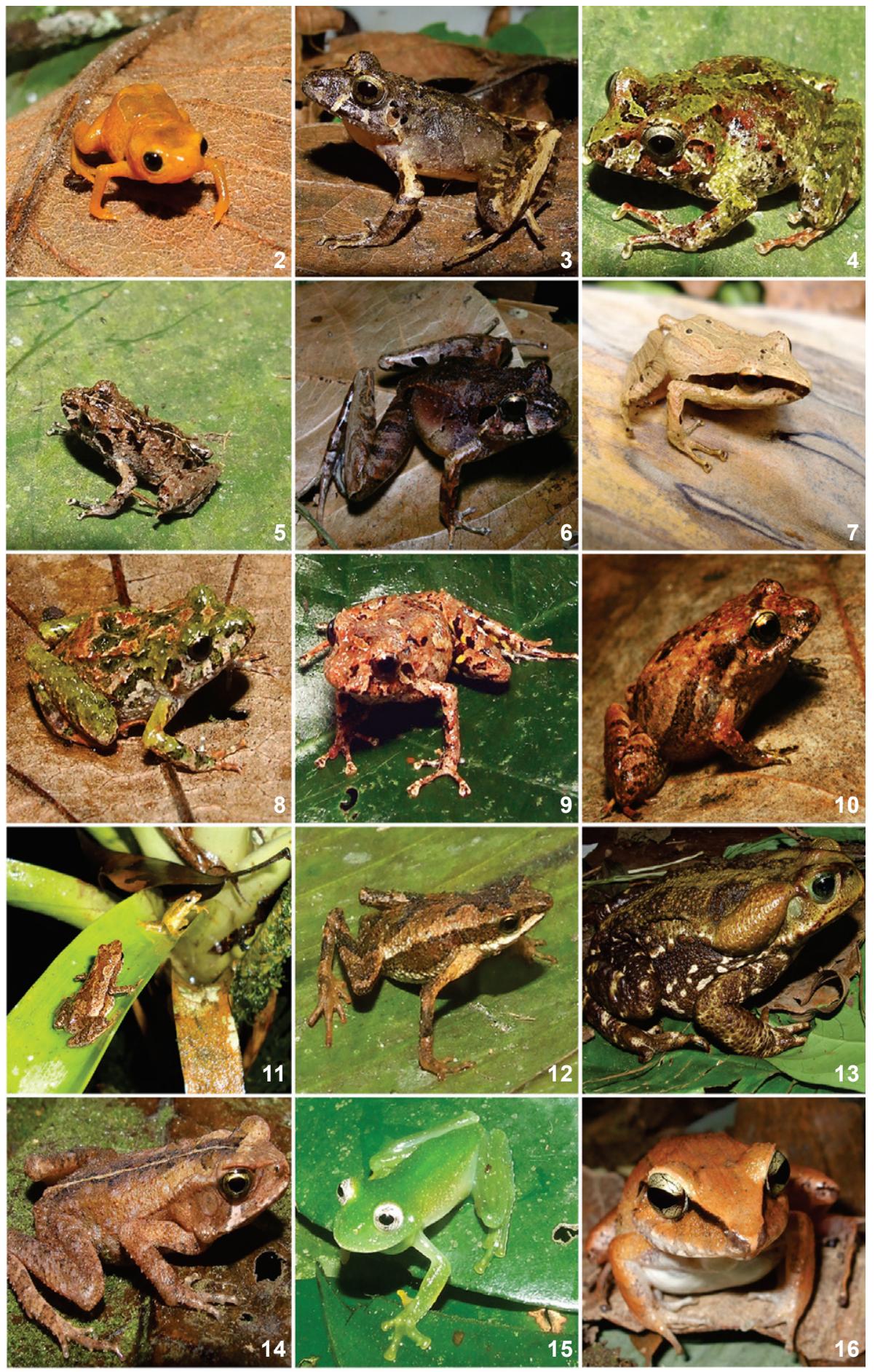

Figures 2-16. Anuran species sampled for the Parque Natural Municipal Nascentes de Paranapiacaba, Santo André, São Paulo state: (2) Brachycephalus sp.; (3) Ischnocnema sp. (aff. guentheri); (4) Ischnocnema sp. (lactea series); (5) Ischnocnema cf. spanios; (6) Ischnocnema guentheri; (7) Ischnocnema hoehnei; (8) Ischnocnema juipoca; (9) Ischnocnema nigriventris (10) Ischnocnema parva; (11) Dendrophryniscus brevipollicatus; (12) Dendrophryniscus cf. brevipollicatus; (13) Rhinella icterica; (14) Rhinella ornata; (15) Vitreorana uranoscopa; (16) Haddadus binotatus; (17) Cycloramphus dubius (ZUEC 6859). Photos: Vivian C. Trevine, except: 6, 10 (Juan Camilo Arredondo). 


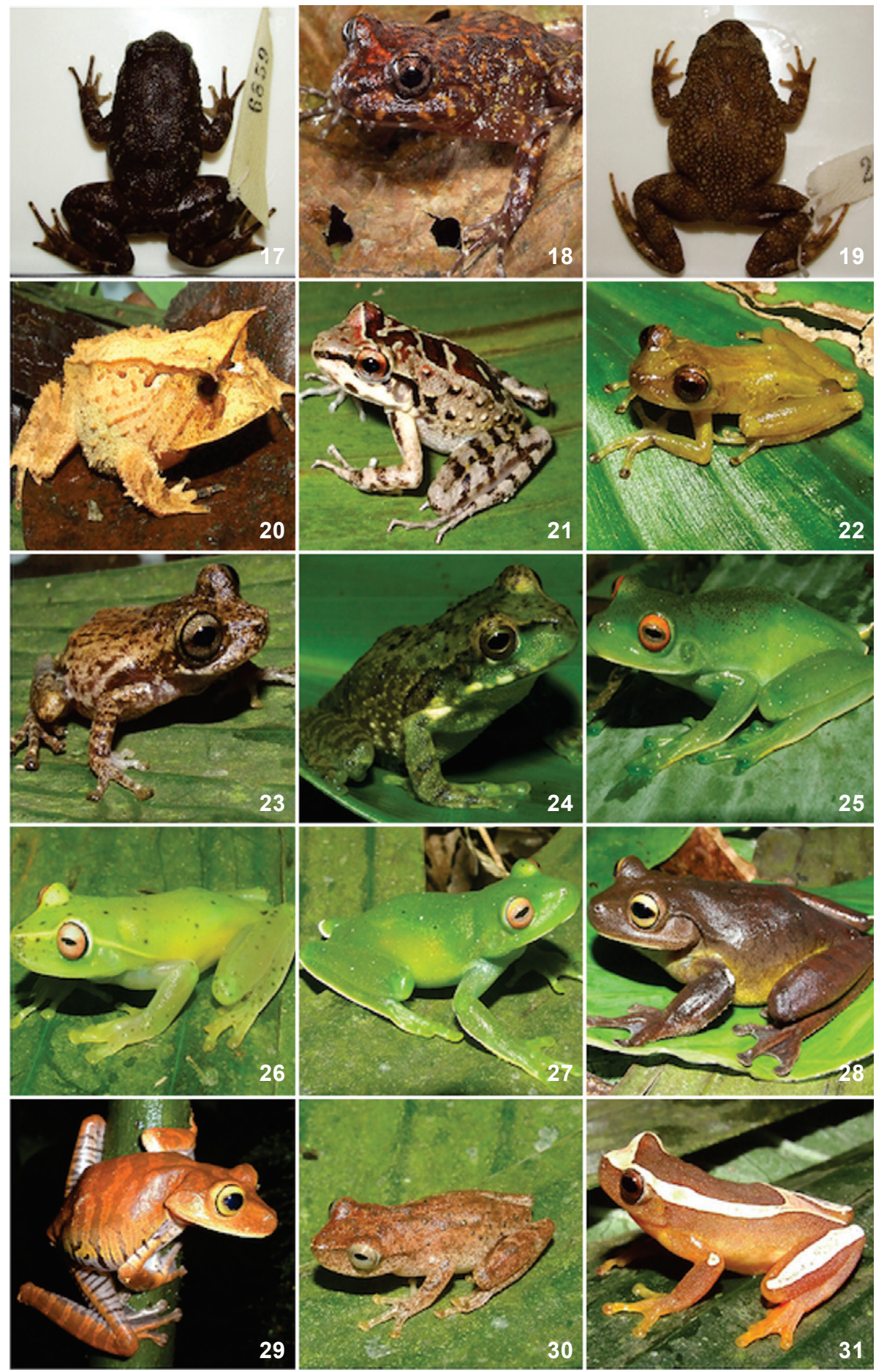

Figures 18-31. Anuran species sampled for the Parque Natural Municipal Nascentes de Paranapiacaba, Santo André, São Paulo state: (18) Cycloramphus eleutherodactylus; (19) Cycloramphus semipalmatus (ZUEC 2722); (20) Proceratophrys melanopogon; (21) Thoropa taophora; (22) Fritziana fissilis; (23) Fritziana ohausi; (24) Gastrotheca fulvorufa; (25) Aplastodiscus albosignatus; (26) Aplastodiscus arildae; (27) Aplastodiscus leucopygius; (28) Bokermannohyla circumdata; (29) Bokermannohyla hylax; (30) Dendropsophus berthalutzae; (31) Dendropsophus elegans. Photos: Vivian C. Trevine, except: 24 (Juan Camilo Arredondo). 

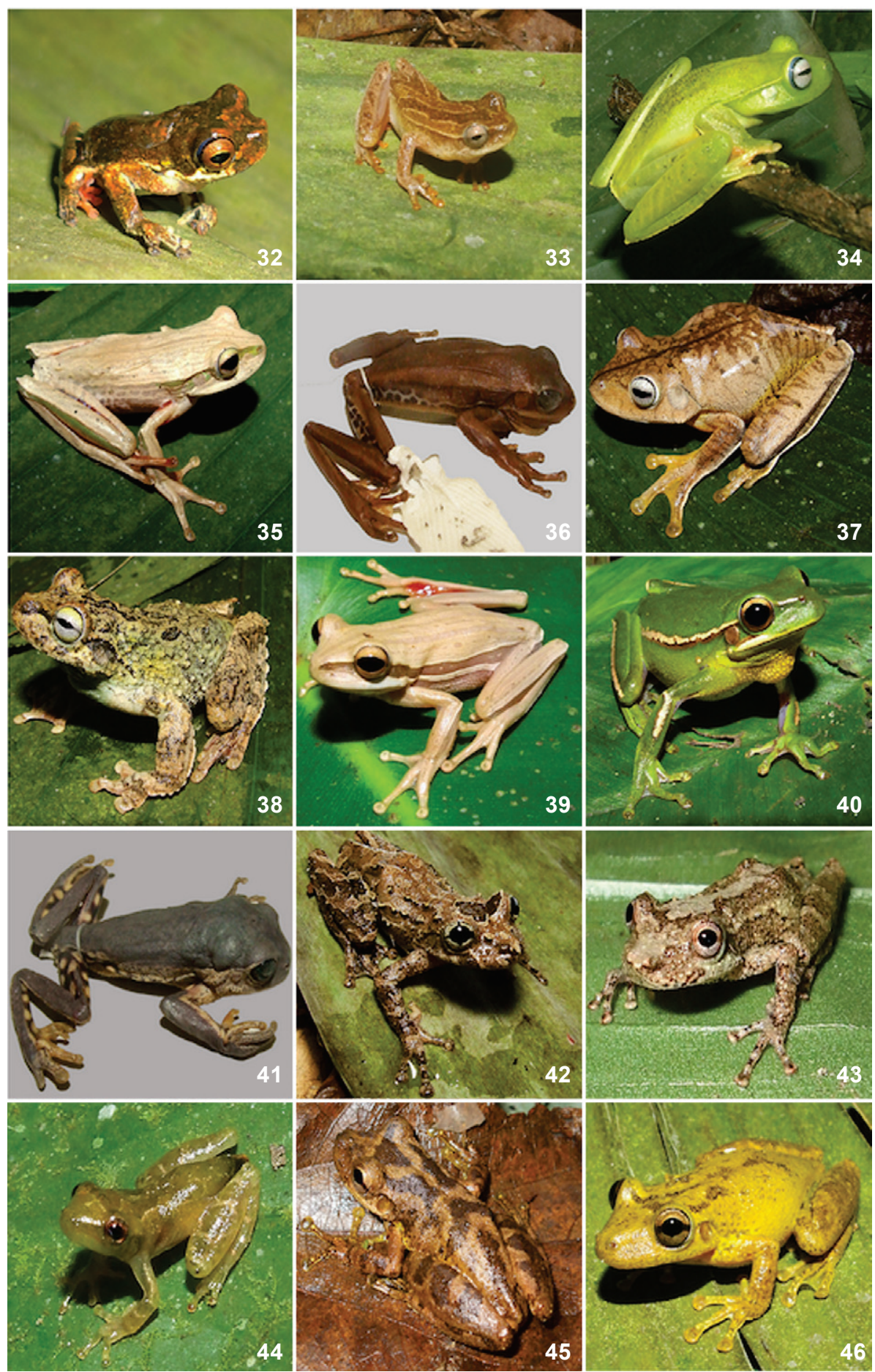

Figures 32-46. Anuran species sampled for the Parque Natural Municipal Nascentes de Paranapiacaba, Santo André, São Paulo state: (32) Dendropsophus microps; (33) Dendropsophus minutus; (34) Hypsiboas albomarginatus; (35) Hypsiboas bischoffi; (36) Hypsiboas cymbalum (MZUSP 74194); (37) Hypsiboas faber; (38) Hypsiboas pardalis; (39) Hypsiboas bandeirantes; (40) Hypsiboas prasinus; (41) Phyllomedusa rohdei (MZSUP 81306); (42) Scinax brieni; (43) Scinax cf. perpusillus; (44) Scinax crospedospilus; (45) Scinax fuscovarius; (46) Scinax hayii. Photos: Vivian C. Trevine. 

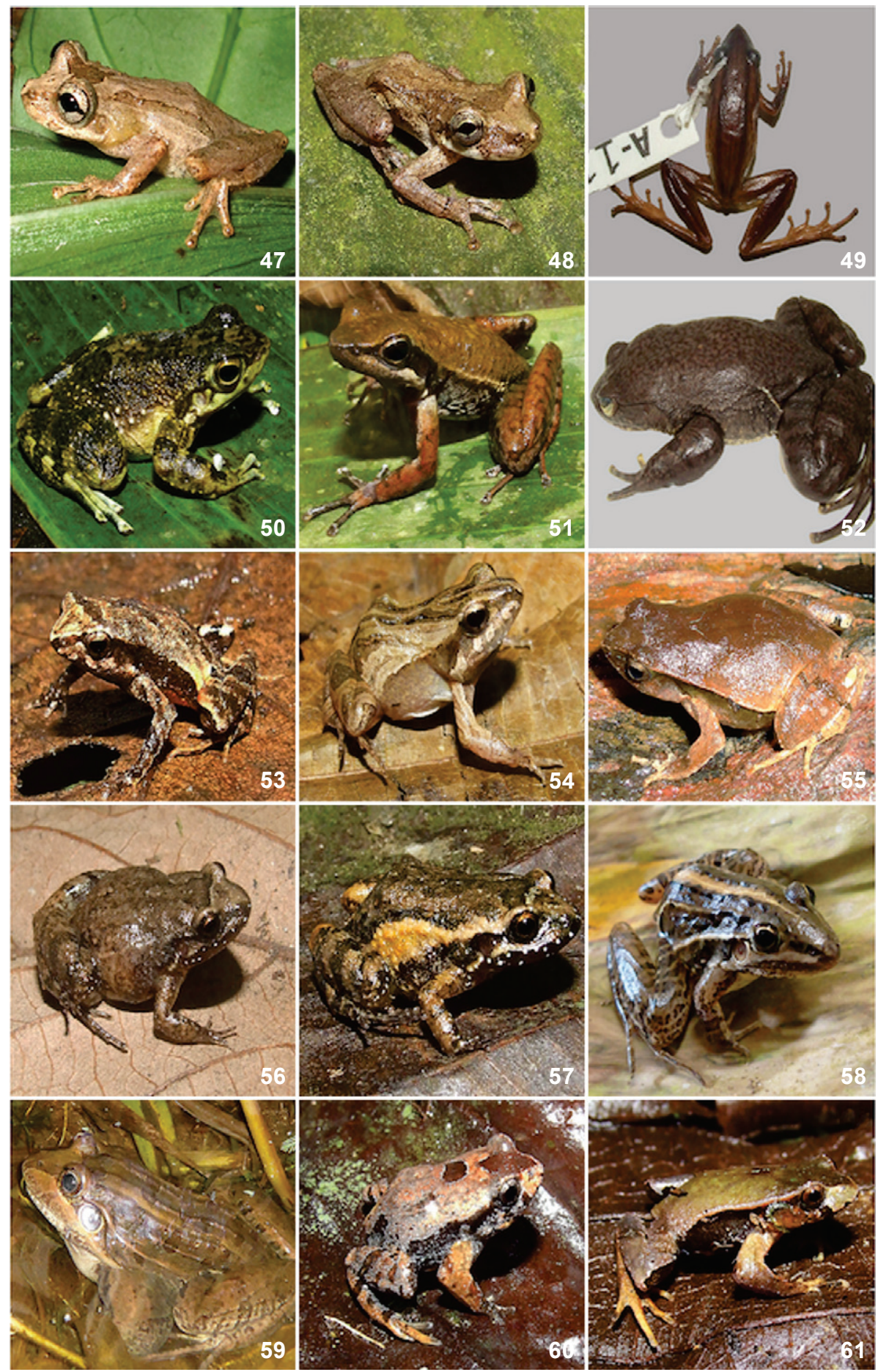

Figures 47-61. Anuran species sampled for the Parque Natural Municipal Nascentes de Paranapiacaba, Santo André, São Paulo state: (47) Scinax hiemalis; (48) Scinax rizibilis; (49) Scinax squalirostris (MZUSP 113525); (50) Hylodes asper; (51) Hylodes sp. (aff. phyllodes); (52) Megaelosia massarti (ZUEC 8516); (53) Physalaemus bokermanni; (54) Physalaemus cuvieri; (55) Physalaemus moreirae; (56) Leptodactylus ajurauna; (57) Leptodactylus cf. marmoratus; (58) Leptodacylus jolyi; (59) Leptodactylus latrans; (60) Paratelmatobius cardosoi; (61) Paratelmatobius poecilogaster. Photos: Vivian C. Trevine. 
however, also occur outside the Atlantic forest (46.4\%), in the Cerrado or the Amazon (Table II).

Pitfall trap data yielded 137 specimens from 10 species of Squamata reptiles. The predominant families were Gymnophtalmidae and Dipsadidae. Nonetheless, the dominant species was the leiosaurid Enyalius ssp, with $89 \%$ of all the records, whereas E. perditus (93 individuals, 67.4\%) predominated over its congeneric E. iheringii (30 individuals, 21.7\%). Four species exhibited intermediary abundance, the lizards Ecpleopus gaudichaudii (three individuals, 2.1\%), Colobodactylus taunayii (two individuals, 1.4\%), Placosoma glabellum (two individuals, 1.4\%), and the snakes Bothrops jararaca (two individuals, 1.4\%) and Erythrolamprus aesculapii (two individuals, 1.4\%). Other three species (Placosoma cordilynum, Taeniophallus bilineatus, and Atractus serranus) were considered rare, and were represented by only one specimen.

The species accumulation curve for the reptiles sampled by pitfall traps could not be stabilized, even though it showed a slight tendency for stabilization (Fig. 62). The calculated richness index (Jack1 = $14.9 \pm 1.9$ ) suggests that the absolute reptile diversity has not yet been sampled by this method.

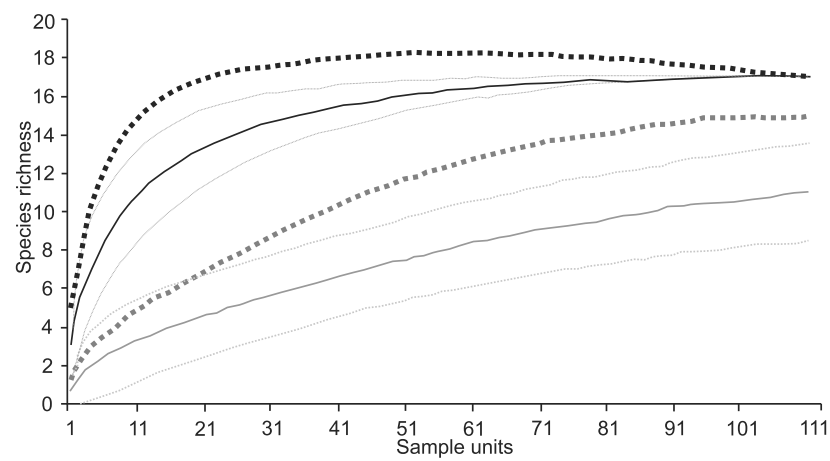

Figure 62. Species accumulation curves (solid lines) and richness index (first order Jackknife) for amphibians (black) and reptiles (grey) sampled by pitfall traps during field surveys in the Parque Natural Municipal Nascentes de Paranapiacaba, Santo André, São Paulo. Dashed lines represent respective standard deviation.

\section{DISCUSSION}

\section{Species composition}

The amphibian diversity recorded for Paranapiacaba (80 ssp.) in this work is higher than the diversity known for the Estação Ecológica de Boracéia (67 ssp.), which has been considered the most distinctive area in São Paulo in terms of amphibian diversity (Heyer et al. 1990, Araújo et al. 2009a). The diversity of reptiles (56 ssp) was also very representative for the state (Condez et al. 2009, Forlani et al. 2010).

We recorded 15 anuran species for Paranapiacaba that were not present in previous records: Ischnocnema cf. spanios,
Ischnonema sp. (gr. lactea), Dendrophryniscus cf. brevipollicatus, Aplastodiscus arildae, Dendropsophus elegans, D. nanus, Phrynomedusa appendiculata, Phyllomedusa rohdei, Scinax squalirostris, S. hiemalis, Leptodactylus ajurauna, and Holoaden suarezi; and also the undescribed Brachycephalus sp., Ischnocnema sp. (aff. guentheri), and Hylodes sp.(aff. phyllodes). Some species cited in VERDADE et al. (2009) were not considered here and are mentioned in the taxonomical comments.

Simultaneously, 27 species of reptiles were added to previously published data for the area: 16 snakes, seven lizards, two amphisbeanids, and two chelonians (MARQUes 2009). Contrary to MARQUEs (2009), we did not consider the following species: Leposternon microcephalum, Kentropyx paulensis, Chironius fuscus, C. foveatus, Pseudoboa serrana, Siphlophis pulcher, and Bothrops jararacussu. Even though their distribution range may include Paranapiacaba, there were no collection records corroborating their presence in the region. However, this may be the result of life habitat, altitudinal range or collection bias, and it is possible that these species will be recorded for the region in the near future. The only exception is the lizard Kentropyx paulensis, listed in Marques (2009), which is an endemic of Cerrado formations (Valdujo et al. 2009).

Some records were not included in our list, such as Erythrolamprus typhlus and Thamnodynastes strigatus. Those snakes have been registered for nearby localities. However, as we were not able to match specimens to a precise geographic coordinate, their presence in the PNMNP could not be confirmed. On the other hand, species such as Amphisbaena alba, A. dubia, Atractus reticulatus, Erythrolamprus jaegeri, Oxyrhopus guibei, and Sibynomorphus mikanii were included as probable occurrences. Although they are not believed to occur within the PNMNP boundaries, their distribution is expected for the macro region where Paranapiacaba is inserted (MARQues et al. 2009), with records for Santo André and adjacent municipalities. One single collection record was catalogued for the snake Echinanthera melanostigma (IB 1640). However, as the authors could not confirm the identification of the specimen, this species was not included herein.

According to the species accumulation curve, the pitfall trap method was efficient in sampling leaf litter anurans. Reptile diversity was not fully sampled by this method, and we expect that an increased sampling effort would have collected a number of additional species.

Altitudinal factors play an important role in the species composition of the Atlantic Forest Domain (HeYER et al. 1990, VAsConcelos et al. 2010), and altitude seems to be a limiting factor for some species at Paranapiacaba, for instance the snakes Bothrops jararacussu and Chironius laevicollis (MARQUes 2009). Alternatively, some species are restricted to elevated areas, for example Heterodactylus imbricatus and Atractus serranus. On the other hand, species normally abundant within the Serra do Mar range were scarce in the PNMNP. That appeared to be the case for Hylodes asper, otherwise very common in nearby lo- 
Table II. Species composition of reptiles from Parque Municipal Nascentes de Paranapicaba, Santo André, São Paulo (PNMNP). Type of data collected: 1. Primary data from field surveys during the study period, 2. secondary data gathered from herpetological collection catalogs, 3. secondary data from Marques (2009). Localities of occurrence at site areas: a. Paranapiacaba or Alto da Serra, b. PNMNP (study area), c: Reserva Biológica do Alto da Serra de Paranapicaba, d: Campo Grande da Serra, e: Santo André and adjacent municipalities. Geographical distribution: Par: species exclusive to Paranapiacaba region, S: endemic for the Serra do Mar from São Paulo state, Se: Serra do Mar formation, south and southeastern Brazil, Af: broad distribution within the Atlantic forest, Br: broad distribution in Brazil.

\begin{tabular}{|c|c|c|c|c|}
\hline Family & Species & Data & Site & Distribution \\
\hline \multicolumn{5}{|l|}{ Squamata } \\
\hline \multirow[t]{2}{*}{ Amphisbaenidae } & Amphisbaena alba Linnaeus, 1758 & 2 & $\mathrm{e}$ & $\mathrm{Br}$ \\
\hline & Amphisbaena dubia Müller, 1924 & 2 & $\mathrm{e}$ & $\mathrm{Br}$ \\
\hline \multicolumn{5}{|l|}{ Lacertilia } \\
\hline \multirow[t]{2}{*}{ Anguidae } & Diploglossus fasciatus (Gray, 1831) & 2,3 & a & $\mathrm{Br}$ \\
\hline & Ophiodes cf. fragilis Spix, 1824 & $1,2,3$ & $a, b, c$ & $\mathrm{Br}$ \\
\hline Gekkonidae & Hemidactylus mabouia Moreau de Jonnès, 1818 & 1,2 & b, e & $\mathrm{Br}$ \\
\hline \multirow[t]{5}{*}{ Gymnophtalmidae } & Colobodactylus taunayi (Amaral, 1933) & 1 & $\mathrm{~b}$ & Af \\
\hline & Ecpleopus gaudichaudii Duméril \& Bibron, 1839 & 1 & $\mathrm{~b}$ & Af \\
\hline & Heterodactylus imbricatus Spix, 1825 & 1 & $\mathrm{~b}$ & Af \\
\hline & Placosoma cordylinum champsonotus (Tschudi, 1847) & 1 & $\mathrm{~b}$ & Af \\
\hline & Placosoma glabellum Peters, 1870 & 1 & $\mathrm{~b}$ & Af \\
\hline \multirow[t]{4}{*}{ Leiosauridae } & Anisolepis grilii Boulenger, 1891 & 2,3 & e & Af \\
\hline & Enyalius iheringii Boulenger, 1885 & $1,2,3$ & $b, c$ & Af \\
\hline & Enyalius perditus Jackson, 1978 & $1,2,3$ & $b, c$ & Af \\
\hline & Urostrophus vautieri Duméril \& Bibron, 1837 & 2,3 & a & $\mathrm{Br}$ \\
\hline Teidae & Salvator merianae (Duméril \& Bibron, 1839) & 1,2 & $b, c, e$ & $\mathrm{Br}$ \\
\hline \multicolumn{5}{|l|}{ Serpentes } \\
\hline \multirow[t]{6}{*}{ Colubridae } & Chironius bicarinatus Wied, 1820 & $1,2,3$ & $b, d, e$ & Af \\
\hline & Chironius exoletus (Linnaeus, 1758) & 2,3 & $\mathrm{e}$ & $\mathrm{Br}$ \\
\hline & Chironius laevicollis (Wied, 1824) & 2,3 & $\mathrm{e}$ & $\mathrm{Br}$ \\
\hline & Pseustes sulphureus (Wagler, 1824) & 2 & a & $\mathrm{Br}$ \\
\hline & Spilotes pullatus (Linnaeus, 1758) & 2,3 & $a, b$ & $\mathrm{Br}$ \\
\hline & Tantilla melanocephala (Linnaeus, 1758) & 2 & a & $\mathrm{Br}$ \\
\hline \multirow[t]{19}{*}{ Dipsadidae } & Atractus pantostictus Fernandes \& Puorto, 1993 & 2 & a & $\mathrm{Br}$ \\
\hline & Atractus reticulatus (Boulenger, 1885) & 2 & e & $\mathrm{Br}$ \\
\hline & Atractus serranus Amaral, 1930 & $1,2,3$ & $a, b$ & $\mathrm{~s}$ \\
\hline & Atractus zebrinus (Jan, 1862) & 1 & $\mathrm{~b}$ & Af \\
\hline & Clelia plumbea (Wied, 1820) & 2,3 & c & $\mathrm{Br}$ \\
\hline & Dipsas alternans Fischer, 1885 & 2 & a & Af \\
\hline & Dipsas indica Laurenti, 1768 & 2 & $\mathrm{e}$ & Se \\
\hline & Echinanthera cephalostriata Di Bernardo, 1996 & $1,2,3$ & $\mathrm{~b}$ & Af \\
\hline & Echinanthera undulata (Wied, 1824) & $1,2,3$ & $a, b, d$ & Af \\
\hline & Elapomorphus quinquelineatus (Raddi, 1820) & $1,2,3$ & $a, b$ & Af \\
\hline & Erythrolamprus aesculapii Linnaeus, 1758 & $1,2,3$ & $b, e$ & $\mathrm{Br}$ \\
\hline & Erythrolamprus jaegeri (Gunther, 1858) & 2 & e & $\mathrm{Br}$ \\
\hline & Erythrolamprus miliaris Linnaeus, 1758 & $1,2,3$ & $\mathrm{~b}$ & $\mathrm{Br}$ \\
\hline & Helicops modestus Günther, 1861 & 2 & $\mathrm{~b}, \mathrm{e}$ & Se \\
\hline & Imantodes cenchoa (Linnaeus, 1758) & 2,3 & a & $\mathrm{Br}$ \\
\hline & Oxyrhopus clathratus Duméril, Bibron \& Duméril, 1854 & $1,2,3$ & $a, b, d$ & Af \\
\hline & Oxyrhopus guibei Hoge \& Romano, 1977 & 2 & e & $\mathrm{Br}$ \\
\hline & Philodryas aestiva (Duméril, Bibron \& Duméril, 1854) & 2,3 & $b, e$ & $\mathrm{Br}$ \\
\hline & & & & Continues \\
\hline
\end{tabular}

ZOOLOGIA 31 (2): 126-146, April, 2014 
Table II. Continueed.

\begin{tabular}{|c|c|c|c|c|}
\hline Family & Species & Data & Site & Distribution \\
\hline & Philodryas patagoniensis (Girard, 1858) & 1,2 & $\mathrm{e}$ & $\mathrm{Br}$ \\
\hline & Sibynomorphus mikanii (Schlegel, 1837) & 2 & $\mathrm{e}$ & $\mathrm{Br}$ \\
\hline & Siphlophis longicaudatus (Andersson, 1901) & 2,3 & a & Af \\
\hline & Taeniophallus affinis (Günther, 1858) & $1,2,3$ & $a, b, e$ & Af \\
\hline & Taeniophallus bilineatus (Fischer, 1885) & $1,2,3$ & $\mathrm{~b}$ & Af \\
\hline & Thamnodynastes sp. 1 & 2 & $\mathrm{a}, \mathrm{e}$ & Se \\
\hline & Tomodon dorsatus Duméril, Bibron \& Duméril, 1854 & $1,2,3$ & $a, b, e$ & Af \\
\hline & Tropidodryas serra (Schlegel, 1837) & 2 & a & Af \\
\hline & Tropidodryas striaticeps (Cope, 1869) & 2,3 & a & Af \\
\hline & Xenodon merremii (Wagler, 1824) & 2 & $\mathrm{a}, \mathrm{e}$ & $\mathrm{Br}$ \\
\hline & Xenodon neuwiedii Günther, 1863 & $1,2,3$ & $a, b$ & $\mathrm{Br}$ \\
\hline Elapidae & Micrurus corallinus (Merrem, 1820) & 2,3 & a & $\mathrm{Se}$ \\
\hline Tropidophiidae & Tropidophis paucisquamis (Müller, 1901) & 2 & $d$ & Se \\
\hline \multicolumn{5}{|l|}{ Testudines } \\
\hline \multirow[t]{2}{*}{ Chelidae } & Hydromedusa maximiliani Mikan, 1820 & 1,2 & $b, e$ & $\mathrm{Se}$ \\
\hline & Hydromedusa tectifera Cope, 1869 & 1 & $\mathrm{~b}$ & $\mathrm{Br}$ \\
\hline
\end{tabular}

calities (PAтto \& Pie 2006). Only five specimens were collected in the area PNMNP area during the entire study period, whereas at least 20 individuals were visualized within few minutes of active daily search in a proximal locality, on the Serra do Mar slope.

Variables such as high humidity and the almost continuous rainy season certainly play an important role in species assemblages in Paranapiacaba, especially for anurans. For instance, the substantial diversity (11 species) of anurans that have direct development (Brachycephalidae) could account for these favorable climatic conditions. The dominance of brachycephalids appears to be a recurrent pattern among Neotropical litter frog faunas (Scott 1976, Duellman 1988, Heinen 1992, Giaretta et al. 1997, 1999, Rocha et al. 2001, 2007, VAN Sluys et al. 2007, AlmeIDAGomes et al. 2008, Santos-Pereira et al. 2011, Siqueira et al. 2011), and it is possibly associated with higher humidity values in cloud forests of higher altitudes (GIARETTA et al. 1999).

The relationship between altitudinal gradients and richness and equitativity of reptile species in the Neotropical region has been debated (SCOtT 1976, Fauth 1989, Hofer \& Bersier 2001, Dixo \& Verdade 2006, Vasconcelos et al. 2010) and not fully understood for the Atlantic forest. However, there is an apparent pattern for Atlantic forest localities: frog density seems to be higher in leaf litter assemblages collected in higher altitudes. This pattern has been corroborated for a few localities (Giaretta et al. 1999, Vasconcelos et al. 2010, Siqueira et al. 2011). In the present work, the overall abundance of leaf litter anurans was higher than in lower altitudes (RocHa et al. 2001, 2007, VAN SLuYs et al. 2007).
Paranapiacaba is the type locality of 23 species of anurans. Historical exploration of the area and the considerable sampling effort made by zoologists during decades could account for such a diverse species catalog. Nevertheless, as one examines anuran diversity in adjacent areas (Estação Ecológica de Boracéia and Parque das Neblinas) (HeYer et al. 1990, BERNECK et al. 2008, 2013, GARCIA et al. 2009b), a gradient of high diversity and similar species composition can be observed throughout this portion of the Serra do Mar.

\section{Taxonomic comments}

The taxonomic status of several species that occur in Paranapiacaba has been intricate (Giaretta \& Castanho 1990, Pombal \& Cruz 1999). Even though we do not intend to provide a taxonomic review of each group, we do consider necessary to elucidate a few taxonomic aspects of some species.

VERDADE et al. (2009) mentioned Brachycephalus ephippium for the REBIO and Paranapiacaba. However, through the analysis of collected specimens and their life habits, we believe that this taxon represents an undescribed species, differentiated from B. ephippium by its darker dorsal coloration and ossification pattern. Brachycephalus sp. is currently being described by Paulo Garcia and collaborators for the Parque das Neblinas, municipality of Mogi das Cruzes. The species seems to be restricted to the most superficial leaf litter layers, and active individuals were always found hidden under leaves, differing from the typical pattern of B. ephippium (Pombal et al. 1994).

Another new brachycephalid sampled, Ischnocnema sp. (aff. guentheri), can be distinguished from the congeneric $I$. guentheri by a suite of characters that include vocalization and 

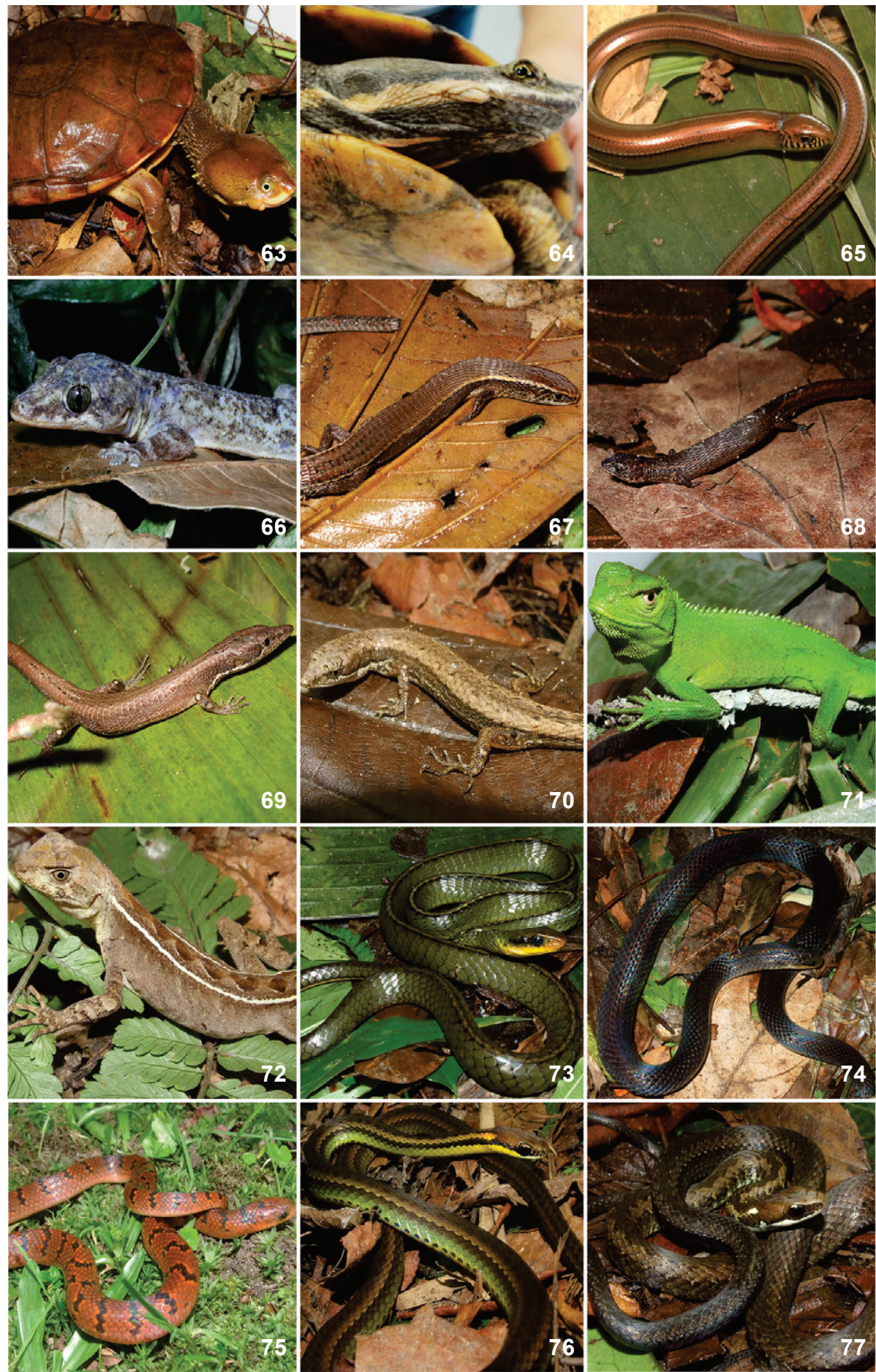

Figures 63-77. Reptile species sampled for the Parque Natural Municipal Nascentes de Paranapiacaba, Santo André, São Paulo state: (63) Hydromedusa maximiliani; (64) Hydromedusa tectifera; (65) Ophiodes cf. fragilis; (66) Hemidactylus mabouia; (67) Colobodactylus taunayi; (68) Ecpleopus gaudichaudii; (69) Placosoma cordylinum champsonotus; (70) Placosoma glabellum; (71) Enyalius iheringii; (72) Enyalius perditus; (73) Chironius bicarinatus; (74) Atractus serranus; (75) Atractus zebrinus; (76) Echinanthera cephalostriata; (77) Echinanthera undulata. Photoss: Vivian C. Trevine, except: 64 (Ingo Grantsau), 66 (Juan Camilo Arredondo). 

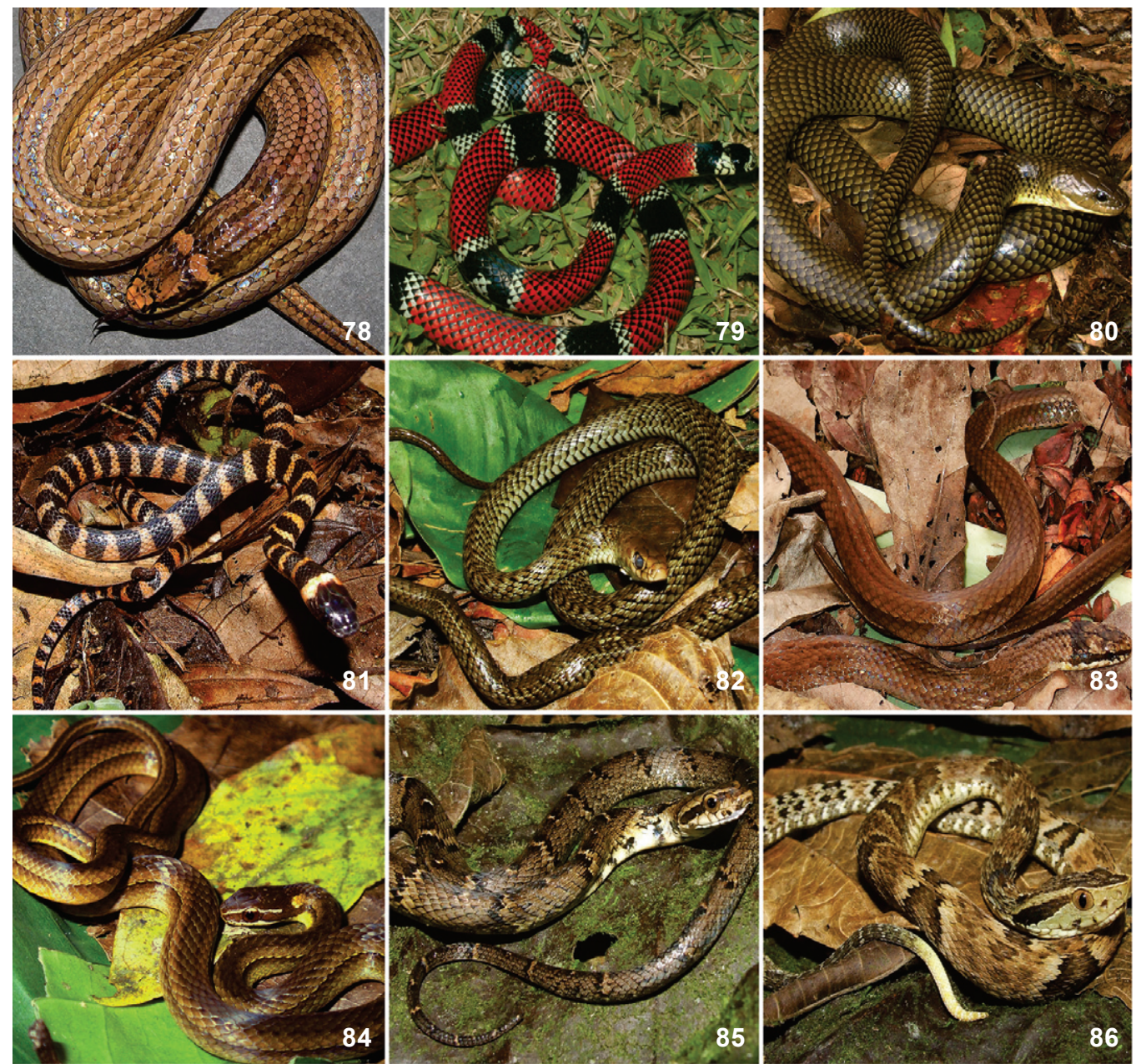

Figures 78-86. Reptile species sampled for the Parque Natural Municipal Nascentes de Paranapiacaba, Santo André, São Paulo state: (78) Elapomorphus quinquelineatus; (79) Erythrolamprus aesculapii; (80) Erythrolamprus miliaris; (81) Oxyrhopus clathratus; (82) Philodryas patagoniensis; (83) Taeniophallus affinis; (84). Taeniophallus bilineatus; (85) Xenodon neuwiedii; (86) Bothrops jararaca. Photoss: Vivian C. Trevine, except: 78 (Ingo Grantsau), and 84 (Alexandre Missassi).

larger male size (CRC: $30.3 \mathrm{~mm}$ ) (Clarissa Canedo pers. com.). However, only a more representative sampling of the population and a broader taxonomic revision including the large complex under the name of $I$. guentheri, will provide sufficient grounds to diagnose this new species.

The Ischnocnema lactea group represents a complex of 14 species distributed in the Atlantic forest, from Rio de Janeiro to Santa Catarina (Hedges et al. 2008), and Bahia (Canedo \& Pimenta 2010). During our field surveys, we collected three species from this complex: Ischnocnema sp. (gr. lactea), I. cf. spanios, and $I$. nigriventris. Ischnocnema lactea is known exclusively from the holotype, and its precarious conservation status is responsible for misleading identifications (CANedo \& Pimenta 2010). The specimens collected by us match the original description in characteristics such as enhanced apical discs with a bifid pattern, absence of webbing, and reduced first hand disc (MirandA-Ribeiro 1926). However, we would need the species to be re-described to arrive at a reliable identification. Therefore, we maintain the taxonomic status of the population found in PNMNP as Ischnocnema sp., pending further revision of the group.

Ischnocnema cf. spanios has been considered restricted to its type locality (Estação Ecológica de Boracéia, São Paulo), but similar specimens were collected from the Atlantic plateau as well, for instance the Parque Estadual de Carlos Botelho and adjacent regions (Forlani et al. 2010). Still, it is possible that such records refer to more than one taxonomically distinct entity under one name, and a reassessment of the group is necessary for further considerations.

Ischnocnema nigriventris is a small species described for the locality known as "Alto da Serra" (Paranapiacaba) 
(BoKERMANN 1966). The species is underrepresented in scientific collections and, because it had an ill-defined type series there used to be a lot of confusion about its identification until it was recently redescribed (BERNECK et al. 2013). Based on the pattern of dark and light blotches on the venter and inner portions of the thighs, enlarged distal discs on external fingers and toes, dorsal and palpebrous tubercles, and a prominent calcar tubercle (Heyer 1985, Heyer et al. 1990, Pombal \& Cruz 1999, BERNECK et al. 2013) we recognize the population collected in the present study as Ischnocnema nigriventris.

The bufonid Dendrophryniscus cf. brevipollicatus resembles its sympatric $D$. brevipollicatus, except for the presence of a white rostral band in D. leucomystax. However, morphological and molecular studies on this genus are required for a better taxonomic resolution of the complex.

Scinax perpusillus identified by us might actually correspond to more than one nominal species (Heyer et al. 1990, Faivovich et al. 2005). Therefore, sampled specimens were listed as $S$. cf. perpusillus.

VERDADE et al. (2009) mentioned the following anurans for the Paranapiacaba region: Leptodactylus gracilis, Rhinella hoogmoedi, Scinax fuscomarginatus, and Gastrotheca microdiscus. No additional record was made for $R$. hoogmoedi and $S$. fuscomarginatus, therefore their occurrence there cannot be corroborated. Leptodactylus gracilis is known to occur in southeastern and southern Brazil. However, its distributional range does not include the state of São Paulo (Araújo et al. 2009b, RossaFEREs et al. 2011). Specimens deposited in the MZUSP correspond to Leptodactylus jolyi, and therefore, L. jolyi seems to be the taxon that occurs in Paranapiacaba. On the other hand, the only Gastrotheca sampled for the PNMNP corresponds to the description available for G. fulvorufa (CARAmaschi \& Rodrigues 2007, IzeCKSOHN \& CARVALHO-E-Silva 2008). The latter was described for Paranapiacaba, and was recently removed from synonymy with G. microdiscus (CARAMASCHI \& RODRIgues 2007).

Among hylodids, Hylodes spp. and Crossodactylus spp are problematic. The taxonomy of Crossodactylus is confusing, and morphological diagnostic characters are misleading (Heyer et al. 1990). One specimen resembling a young Crossodactylus was collected in a neighboring area, on the Serra do Mar slope. We were not able to provide a precise identification for that specimen. Collection records, however, confirm at least two species occurring in the region, C. dispar and C. gaudichaudii (see discussion below). Hence, our records for this genus are based solely on secondary data. Hylodes sp. (aff. phyllodes) is closely related to $H$. phyllodes. The large size of the male (CRC: $33.7-$ $35.9 \mathrm{~mm}$ ), contrasting with the male of $H$. phyllodes (CRC: 27.6$30.0 \mathrm{~mm}$ ), as well as the coloration pattern of specimens, might be diagnostic for this new species. However, diagnostic characters still need to be established.

Difficulties identifying cryptic species of the Leptodactylus marmoratus complex (sensu HeYer 1973) are common (POMBAL \& GoRdo 2004, BernecK et al. 2008). The epithet "marmoratus" does not seem to apply to the populations from Paranapiacaba and Boracéia (BERNECK et al. 2008), and it is possible that more than one species occur at the PNMNP.

The Holoaden specimen recorded for Paranapiacaba (MZUSP 891) was erroneously cited for Campos do Jordão, São Paulo state, and posteriorly defined as the paralectotype of $H$. luederwaldti (Miranda-Ribeiro 1920, Lutz 1958, Caramaschi \& Pombal JR 2006). The mistake was corrected and the specimen was recently described as $H$. suarezi (MARTINs \& ZAHER 2013). It is also found in the Estação Ecológica de Boracéia, the Parque Nacional da Serra da Bocaína and the Estação Ecológica do Bananal (Pombal Jr et al. 2008, Martins 2010, Martins \& Zaher 2013).

Species boundaries are not very clear within the lizard genus Ophiodes. The specimens collected from the PNNMP correspond to Ophiodes fragilis (MÁrcio borges-Martins, pers.com.), and we follow that classification until a proper revision is available.

The snake Dipsas indica registered by us for Paranapiacaba corresponds to D. indica bucephala (PeTERs 1960). Recent taxonomic changes in the $D$. indica group have resulted in uncertainty about the status of this subspecies (HARVEY \& EMBERT 2008). Therefore, we refrain from unsing the subspecies name here.

The Thamnodynastes recorded for the Paranapiacaba region corresponds to Thamnodynastes "sp. 1" of Franco \& Ferreira (2002). According to the authors, this taxon corresponds to the one described by MiKan (1820) as Coluber nattereri. Menawhile, as there is no formal redescription available to legitimize the name, the taxon is considered as Thamnodynastes "sp. 1 ".

\section{Conservational status and final comments}

The importance of Paranapiacaba for the conservation of Brazilian amphibians is already well established. It is the single known locality for the only anuran considered to be extinct from Brazil (Phrynomedusa fimbriata), and for another critically endangered species (Hypsiboas cymbalum) (HADDAD 2008, GarCia et al. 2009a). This alone would be sufficient to establish the importance of the region as a primordial site for conservation. However, declines in anuran populations make the region even more important.

A great deal of attention was given in the 1980's, especially for the REBIO, when research revealed the effects of pollution emerging from the petrochemical pole of Cubatão (DomINGos et al. 2009, Lopes et al. 2009). The original vegetation of the area has been altered as a consequence of pollution (Domingos et al. 2000, MoraEs et al. 2002, 2003), and that has impacted several groups of animals, including amphibians (Lopes et al. 2009, Domingos et al. 2009, Sugiyama et al. 2009, Verdade et al. 2011, 2012). According to Verdade et al. $(2009,2011)$, the anurofauna of the REBIO is depauperate, if not in terms of richness, at least in the number of individuals of otherwise common species, for instance Ischnocnema parva. Additionally, the authors indicated that the vegetation physiognomy and the water $\mathrm{pH}$ of the REBIO 
are altered, contrasting with the unaltered $\mathrm{pH}$ values obtained from the PNMNP. It has been postulated that the mountainous portion of the REBIO is under direct influence of the wind current emerging from the petrochemical pole of Cubatão, whereas the PNMNP is apparently more protected from it (FERREIRA et al. 2009, VERDADE et al. 2009). These differences are reflected on the anurofauna: species are clearly more abundant in the PNMNP (VERDADE et al. 2009). Unfortunately, we were not able to sample the REBIO, and further comparisons are hindered until standardized sampling is performed simultaneously in the two conservation units.

The anuran populations of some species are likely declining in southeastern Brazil (Heyer et al. 1988, Weygoldt 1989, ETEROVICK et al. 2005, VeRDADE et al. 2011). A few are considered extinct or are under considerable punctual decline. Examples are Cycloramphus semipalmatus, C. boraceiensis, Crossodactylus dispar, C. gaudichaudii and Hylodes phyllodes for the "Estação Ecológica de Boracéia", state of São Paulo (Heyer et al. 1988); and Cycloramphus fuliginosus and Crossodactylus spp for Santa Teresa, state of Espírito Santo (WEYGoldT 1989).

Much of the information in the literature is merely speculative. A great diversity of factors might contribute to apparent reductions in population size. Life habitats associated with mountainous streams may be related to environmental sensibility of some of those supposedly declining anurans (HEYER et al. 1988, Stuart et al. 2004, Lips et al. 2005, Verdade et al. 2011). On the other hand, various factors could influence such alterations, such as low population density, stochastic effects caused by natural selection, distributional patterns within the Serra do Mar range, collection biases, or even natural population fluctuations (Heyer et al. 1988, Heyer \& MAXSON 1983, MAgnusson et al. 1999).

Nevertheless, even though we strongly recommend caution when evaluating patterns of population decline, we stress that species that now seem to be rarer were frequently collected during campaigns between 1950 and 1980, as documented in collection catalogs from MZUSP and ZUEC (see Appendix 1). Human interference, especially on adjacent areas of the Paranapiacaba village, appears to have played an important role on the current local species composition and loss of biodiversity. As a result from the operation of the railroad, several forested areas have been completely suppressed. Our inability to delimitating the exact path of past collecting expeditions, due to the lack of geographic coordinates for them, makes it difficult to reach more definite conclusions. Regardless, the results presented herein are relevant enough to indicate the need for future studies.

\section{ACKNOWLEDGEMENTS}

We are grateful to the Secretaria de Gestão de Recursos Naturais de Paranapiacaba e Parque Andreense da Prefeitura de Santo André and IBAMA/ICMBio for collection permits. Ingo
Grantsau for fieldwork assistance, and Carolina Castro-Melo (MZUSP) and Valdir J. Germano (IB) for collection assistance. We are also indebted to Francisco L. Franco (IB), and Felipe Toledo (ZUEC) for permission to access the herpetological collections under their care. To V. Verdade, P. Garcia, I. Martins, B. Berneck, C. Canedo, A. C. Calijorne-Lourenço, D. Baêta, C. Brasileiro, and V. Dill Orrico for information on amphibian taxonomy. VT was supported by a scholarship from Coordenação de Aperfeiçoamento de Pessoal de Nível Superior (CAPES). Funding for this project was provided by Fundação de Amparo à Pesquisa do Estado de São Paulo (BIOTA/FAPESP; grant numbers 2011/50206-9 and 2008/50928-1) to HZ and CFBH, and Conselho Nacional de Desenvolvimento Científico e Tecnológico (CNPq; grant numbers 565046/2010-1; 303545/2010-0) to HZ.

\section{LITERATURE CITED}

Ав'SABer, A.N. 2003. Os Domínios de Natureza no Brasil. Potencialidades Paisagísticas. São Paulo, Ateliê Editorial, 159 p.

Almeida-Gomes, M.; D.Vrcibradic; C.C.Siqueira; M.C. Kiefer; T. Klaion; P.A. Santos; D. Nascimento; C.V. Ariani; V.N.T. Borges-Junior; R.F. Freitas-Filho; M. Van Sluys \& C.F.D. Rocha. 2008. Herpetofauna of an Atlantic rainforest area (Morro São João) in Rio de Janeiro State, Brazil. Anais da Academia Brasileira de Ciências 80 (2): 1-10. doi: 10.1590/S0001-37652008000200007

Araújo, C.O.; T.H. Condez \& R.J. Sawaya. 2009a. Anfíbios Anuros do Parque Estadual das Furnas do Bom Jesus, sudeste do Brasil, e suas relações com outras taxocenoses no Brasil. Biota Neotropica 9 (2): 1-22. doi: 10.1590/S167606032009000200007

AraúJo, O.G.S.; L.F. Toledo; P.C.A. Garcia \& C.F.B. Haddad. 2009b. The amphibians of São Paulo State, Brazil. Biota Neotroprica 9 (4): 1-13. h ttp://dx.doi.org/10.1590/S1676-06032009000400020

Berneck, B.V.M.; C.O.R. Costa \& P.C.A. Garcia. 2008. A new species of Leptodactylus (Anura: Leptodactylidae) from the Atlantic Forest of São Paulo State, Brazil. Zootaxa 1795: 46-56.

Berneck, B.V.M.; M. Targino \& P.C.A. Garcia. 2013. Rediscovery and re-description of Ischnocnema nigriventris (Lutz, 1925) (Anura: Terrarana: Brachycephalidae). Zootaxa 3694: 131142. doi: 10.11646/zootaxa.3694.2.2

Blomberg, S. \& R. Shine. 2006. Reptiles, p. 297-307. In: W.J. Sutherland (Ed.). Ecological census techniques. A handbook. Cambridge, Cambridge University Press, $2^{\text {nd }}$ ed., $\mathrm{XVI}+432 \mathrm{p}$.

BoKermanN, W.C.A. 1966. Lista anotada das localidades tipo de anfíbios brasileiros. São Paulo, RUSP, 183p.

BoKermanN, W.C.A. 1968. Observações sobre "Hyla pardalis" Spix (Anura, Hylidae). Revista Brasileira de Biologia 28 (1): 1-5.

CÂMARA, I.G. 2003. Brief history of conservation in the Atlantic forest, p. 31-42. In: C. Galindo-Leal \& I.G. Câmara (Eds). The Atlantic Forest of South America: biodiversity status, threats, and outlook. Washington, DC, Island Press, 488p. 
Campbell, H.W. \& S.P. Christman. 1982. Field techniques for herpetofaunal community analysis, p. 193-200. In: N.J. Sсотт Jr. (Ed.). Herpetological Communities: a Symposium of the Society for the Study of Amphibians and Reptiles and the Herpetologist's League. Washington D.C., U.S. Department of the Interior, Fish Wildlife Services, IV+239p.

Canedo, C. \& B.V.S. Pimenta. 2010. New species of Ischnocnema (Anura, Brachycephalidae) from the Atlantic Rainforest of the state of Espírito Santo, Brazil. South American Journal of Herpetology 5 (3): 199-206. doi: 10.2994/057.005.0305

Caramaschi, U. \& J.P. Pombal JR. 2006. Notas sobre a série-tipo de Holoaden bradei B. Lutz e Holoaden luederwaldti Miranda-Ribeiro (Anura, Brachycephalidae). Revista Brasileira de Zoologia 23 (4): 1261-1263. doi: 10.1590/S0101-81752006000400039

Caramaschi, U. \& M.T. Rodrigues. 2007. Taxonomic status of the species of Gastrotheca Fitzinger, 1843 (Amphibia, Anura, Amphignathodontidae) of the Atlantic rain Forest os eastern Brazil, with description of a new species. Boletim do Museu Nacional, N.S. Zoologia 525: 1-19.

Caramaschi, U. \& C.A.G. Cruz 2013. A new species of the Hypsiboas polytaenius clade from southeastern Brazil (Anura: Hylidae). South American Journal of Herpetology 8 (2): 121-126.

Carnaval, A.C.; M.J. Hickerson; C.F.B. Haddad; M.T. Rodrigues \& C.M. Moritz. 2009. Stability predicts genetic diversity in the Brazilian Atlantic Forest hotspot. Science 323:785-789. doi: 10.1126/science.1166955

Carrasco, P.A.; C.I. Mttoni; G.C. Leynaud \& G.J. Scrocchi. 2012. Morphology, phylogeny and taxonomy of South American bothropoid pitvipers (Serpentes, Viperidae). Zoologica Scripta 41: 109-124 doi: 10.1111/j.1463-6409.2011.00511.x

Cechin, S.Z. \& M. Martins. 2000. Eficiência de armadilhas de queda (pitfall traps) em amostragens de anfíbios e répteis no Brasil. Revista Brasileira de Zoologia 17: 729-749. doi: 10.1590/S0101-81752000000300017

Colwell, R.K. 2009. EstimateS: Statistical estimation of species richness and shared species from samples. Version 8.2Available online at: http://purl.oclc.org/estimates [Accessed: January, 2011].

Colwell, R.K. \& J.A. Coddington. 1994. Estimating terrestrial biodiversity through extrapolation. Philosophical Transactions of the Royal Society of London B 345: 101118. doi: 10.1098/rstb.1994.0091

Condez, T.H.; R.J. Sawaya \& M. Dixo. 2009. Herpetofauna of the Atlantic Forest remnants of Tapiraí and Piedade region, São Paulo state, southeastern Brazil. Biota Neotropica 9 (1): 157-185.

ConN, P.S. 1994. Standard techniques for inventory and monitoring: straight-line drift fences and pitfall traps, p. 109-117. In: W.R. Heyer; M.A. Donnelly; R.W. McDiarmid, L.C. HAYEK \& M.S. Foster (Eds). Measuring and monitoring biological diversity: standard methods for amphibians. Washington D.C., Smithsoniam Institution Press, 384p.
Crump, M.L. \& J.R. Scott JR. 1994. Standard techniques for inventory and monitoring: visual encounter surveys, p. 8492. In: W.R. Heyer; M.A. Donnelly; R.W. McDiarmid; L.C. HayeK $\&$ M.S. Foster (Eds). Measuring and monitoring biological diversity: standard methods for amphibians. Washington D.C., Smithsoniam Institution Press, 384p.

Cruz, C.A.G. \& R.N. Feio. 2007. Endemismos em anfíbios em áreas de altitude na Mata Atlântica no sudeste do Brasil, p. 117-126. In: L.B. Nascimento \& M.E. Oliveira (Eds). Herpetologia no Brasil II. Curitiba, Sociedade Brasileira de Herpetologia, 354p.

Curcio, F.F.; V.Q. Piacentini \& D.S. Fernandes. 2009. On the status of the snake genera Erythrolamprus Boie, Liophis Wagler and Lygophis Fitzinger (Serpentes, Xenodontinae). Zootaxa 2173: 66-68.

Dixo, M. \& V.K. Verdade. 2006. Herpetofauna de serapilheira da Reserva Florestal do Morro Grande, Cotia (SP). Biota Neotropica 6 (2): 1-20. doi: 10.1590/S1676-06032006000200009

Domingos, M.; M.I.M.S. Lopes \& Y. Struffaldi-de Vuono. 2000. Nutrient cycling disturbance in Atlantic Forest sites affected by air pollution coming from the industrial complex of Cubatão, Southeast Brazil. Revista Brasileira de Botânica 23 (1): 77-85.

Domingos, M.; A. Klumpr \& G. Klumpr. 2009. Poluição atmosférica, uma ameaça à Floresta Atlântica da Reserva Biológica de Paranapiacaba, p. 165-184. In: M.I.M.S. Lopes; M. KIRIZAWA \& M.M.R.F. Melo (Eds). Patrimônio da Reserva Biológica do Alto da Serra de Paranapiacaba. A antiga Estação Biológica do Alto da Serra. São Paulo, Instituto de Botânica, 720p.

Duellman, W.E. 1988. Patterns of species diversity in anuran amphibians in American Neotropics. Annals of the Missouri Botanical Garden 75: 79-104. doi: 10.2307/ 2399467

Eterovick, P.C.; A.C.O.Q. Carnaval; D.M. Borges-Nojosa; D.L. Silvano; M.V. Segalla \& I. Sazima. 2005. Amphibian Declines in Brazil: An Overview. Biotropica 37 (2): 166-179. doi: 10.1111/j.1744-7429.2005.00024.X

Faivovich, J.; C.F.B. Haddad; P.C.A. Garcia; D.R. Frost; J.A. Campbell \& W.C. Wheeler. 2005. Systematic review of the frog family Hylidae, with special reference to Hylinae: Phylogenetic analysis and taxonomic revision. Bulletin of the American Museum of Natural History 294: 1-240. doi: 10.1206/0003-0090(2005)294[0001:SROTFF]2.0.CO;2

Fauth, J.E.; B.I. Сrother \& J.B. Slowinski. 1989. Elevational patterns of species richness, evenness and abundance of the Costa Rican leaf-litter herpetofauna. Biotropica 21 (2): 178185. doi: $10.2307 / 2388708$

Ferreira, C.J.; L.K. Tominaga; J.M.A. Sobrinho \& M.F. Neto. 2009. Geologia e Geomorfologia, p: 53-71. In: M.I.M.S. Lopes; M. Kirizawa \& M.M.R.F. Melo (Eds). Patrimônio da Reserva Biológica do Alto da Serra de Paranapiacaba. A antiga Estação Biológica do Alto da Serra. São Paulo, Instituto de Botânica, 720p. 
Forlani, M.C.; P.H. Bernardo; C.B.F. Haddad \& H. Zaher. 2010. Herpetofauna do Parque Estadual Carlos Botelho, São Paulo, Brasil. Biota Neotropica 10 (3): 265-309. doi.org/ 10.1590/S1676-06032010000300028

Franco, F.L. \& T.G. Ferreira. 2002. Descrição de uma nova espécie de Thamnodynastes Wagler, 1830 (Serpentes, Colubridae) do nordeste brasileiro, com comentários sobre o gênero. Phyllomedusa 1 (2): 57-74.

Frost, D.R. 2013. Amphibian Species of the World: an Online Reference. Version 5.6 (9 January 2013). Electronic Database accessible at http://research.amnh.org/herpetology/ amphibia/index.html. American Museum of Natural History, New York, USA.

Frost, D.R.; R. Etheridge; D. Janies \& T.A. Titus. 2001. Total Evidence, Sequence Alignment, Evolution of Polychrotid Lizards, and a Reclassification of the Iguania (Squamata: Iguania). American Museum Novitates 3343: 1-39. doi: 10.1206/0003-0082(2001)343<0001:TESAEO>2.0.CO;2

Galindo-Leal, C. \& I.G. CÂmara. 2005. Status do hotspot Mata Atlântica: uma síntese, p. 3-11. In: C. GaLINDo-LEAL \& I.G. CÂMARA (Eds). Mata Atlântica: biodiversidade, ameaças e perspectivas. São Paulo, Fundação SOS Mata Atlântica, 471p.

Garcia, P.C.A.; R.J. Sawaya; I.A. Martins; C.A. Brasileiro; V.K. Verdade; J. Jim; M.V. Segalla; M. Martins; D.C. Rossa-Feres; C.F.B. Haddad; L.F. Toledo; C.P.A. Prado; B.M. Berneck \& O.G.S. Araújo. 2009a. Anfíbios, p. 330-347. In: P.M. Bressan; M.C.M KIERULFF \& A.M. Sugieda (Eds). Livro vermelho da fauna ameaçada de extinção do Estado de São Paulo. São Paulo, SEMA, 645p.

GarCiA, P.C.A.; B.V.M. BerNeCK \& C.O.R. Costa 2009b. A new species of Paratelmatobius (Amphibia, Anura, Leptodactylidae) from Atlantic Rain Forest of Southeastern Brazil. South American Journal of Herpetology 4 (3): 217-224. doi: 10.2994/ 057.004.0303

Giaretta, A.A. \& LM. Castanho. 1990. Nova espécie de Paratelmatobius (Amphibia, Anura, Leptodactylidae) da Serra do Mar, Brasil. Papéis Avulsos de Zoologia 37 (8): 133-139.

Giaretta, A.A.; R.J. SaWhya; G. Machado; M.S. AraúJo; K.G. Facure; H.F. Medeiros \& R. Nunes. 1997. Diversity and abundance of litter frogs at altitudinal sites at Serra do Japi, southeastern Brazil. Revista Brasileira de Zoologia 14 (2): 341-346. doi: 10.1590/S0101-81751997000200008

Giaretta, A.A.; K.J. Facure; R.J. Sahaya; J.H.M. Meyer \& N. Chemin. 1999. Diversity and Abundance of Litter Frogs in a Montane Forest of Southeastern Brazil: Seasonal and Altitudinal Changes. Biotropica 31 (4): 669-674. doi: 10.1111/j.17447429.1999.tb00416.x

Gibbons, J.W. \& R.D. Semlitsch. 1982. Terrestrial drift fences with pitfall traps: An effective technique for quantitative sampling of animal populations. Brimleyana 7: 1-16.

Gotelli, N.J. \& R.K. Colwell. 2001. Quantifying biodiversity: procedures and pitfalls in the measurement and comparison of species richness. Ecological Letters 4: 379-391. doi: 10.1046/j.1461-0248.2001.00230.x

Grazziotin, F.G.; H. Zaher; R.W. Murphy; G. Scrocchi; M.A. Benavides; Y. Zhang \& S.L. Bonatto. 2012. Molecular phylogeny of the New World Dipsadidae (Serpentes: Colubroidea): a reappraisal. Cladistics 1: 1-23.

Guix, J.C.; G. Lorentte; A. Montori; M.A. Carretero \& X. Santos. 2000. Una nueva área de elevada riqueza de anuros en el bosque lluvioso atlântico de Brasil. Boletin de la Asociación Herpetolica Española 11 (2): 100-105.

GutJahr, M.R. \& R. TAVAREs. 2009. Clima, p. 39-52. In: M.I.M.S. Lopes; M. KirizaWa \& M.M.R.F. Melo (Eds). Patrimônio da Reserva Biológica do Alto da Serra de Paranapiacaba. A antiga Estação Biológica do Alto da Serra. São Paulo, Instituto de Botânica, 720p.

HADDAD, C.F.B. 2008. Uma Análise da Lista Brasileira de Anfíbios Ameaçados de Extinção, p. 287-320. In: A.B.M. Machado; G.M. Drummond \& A.P. Paglia (Eds). Livro Vermelho da Fauna Brasileira Ameaçada de Extinção. São Paulo, Ministério do Meio Ambiente, vol. 2, 907p.

Harvey, M.B. \& D. Embert. 2008. Review of Bolivian Dipsas (Serpentes: Colubridae), with comments on other South American species. Herpetological Monographs 22: 54-105. doi: 10.1655/07-023.1

Hedges, B.S.; W.E. Duellman \& M.P. Heinicke. 2008. New World direct-developing frogs (Anura: Terrarana): Molecular phylogeny, classification, biogeography, and conservation. Zootaxa 1737: 1-182.

HeInen, J.T. 1992. Comparisons of the Leaf Litter Herpetofauna in Abandoned Cacao Plantations and Primary Rain Forest in Costa Rica: Some Implications for Faunal Restoration. Biotropica 24 (3): 431-439. doi: 10.2307/2388614

Hellmann, J.J. \& G.W. Fowler. 1999. Bias, precision, and accuracy of four measures of species richness. Ecological Applications 9 (3): 824-834. doi: 10.1890/1051-0761(1999)009 [0824:BPAAOF]2.0.CO;2

HELTSCHE, J. F. \& N. E. FORRESTER. 1983. Estimating species richness using the Jackknife procedure. Biometrics, 39: 1-11.

HeYER, W.R. 1973. Systematics of the marmoratus group of the frog genus Leptodactylus (Amphibia, Leptodactylidae). Natural History of the Museum of Los Angeles County 251: $1-50$.

HeYer, W.R. 1985. New species of frogs from Boracéia, São Paulo, Brazil. Proceedings of the Biological Society of Washington 98 (3): 657-671.

HeYer, W.R. \& L.R. Maxson. 1983. Relationships, zoogeography, and speciation mechanisms of frogs of the genus Cycloramphus (Amphibia, Leptodactylidae). Arquivos de Zoologia 30: 341373. doi: 10.11606/issn.2176-7793.v30i4p235-339

Heyer, W.R.; A.S. Rand; C.A.G. Cruz \& O.L. Peixoto. 1988. Decimations, extinctions, and colonizations of frog populations in southeast Brazil and their evolutionary implications. Biotropica 20: 230-235. doi: 10.2307/2388238 
Heyer, W.R.; A.S. Rand; C.A.G. Cruz; O.L. Peixoto \& C.E. Nelson. 1990. Frogs of Boracéia. Arquivos de Zoologia 31 (4): 231-410.

HOFER U. \& L.F. BERSIER. 2001. Herpetofaunal diversity and abundance in tropical upland forests of Cameroon and Panama. Biotropica 33: 142-152.

IUCN. 2010. IUCN Red List of Threatened Species. Version 2010.4. Available at: http://www.iucnredlist.org [Accessed: February 16, 2012].

Izecksohn, E. \& S.P. Carvalho-e-Silva. 2008. As espécies de Gastrotheca Fitzinger na Serra dos Orgãos, Estado do Rio de Janeiro, Brasil (Amphibia: Anura: Amphignathodontidae). Revista Brasileira de Zoologia 25 (1): 100-110. doi: 10.1590/S0101-81752008000100014

KeARNeY, M. 2003. Systematics of the Amphisbaenia (Lepidosauria: Squamata) based on morphological evidence from recent and fossil forms. Herpetological Monographs 17: 1-74. doi: 10.1655/0733-1347(2003)017[0001:SOTALB]2.0.CO;2

Kumar, A. 2010. A tragic loss: Fire at Instituto Butantan, Brazil. Toxicon 56: 1528-1529. doi: 10.1016/j.toxicon.2010.07.002

Laurance, W.F. 2009. Conserving the hottest of the hotspots. Biological Conservation 142: 1137. doi: 10.1016/j.biocon. 2008.10.011

Lopes, M.I.M.S. \& M. Kirizawa. 2009. Reserva Biológica de Paranapiacaba, a antiga Estação Biológica do Alto da Serra: história e visitantes ilustres, p. 15-38. In: M.I.M.S. Lopes; M. KIRIZAWA \& M.M.R.F. Melo (Eds). Patrimônio da Reserva Biológica do Alto da Serra de Paranapiacaba. A antiga Estação Biológica do Alto da Serra. São Paulo, Instituto de Botânica, 720p.

Lopes, M.I.M.S.; A.R. Santos; R.M. Moraes \& M. Kirizana. 2009. Ciclagem de nutrientes e alterações no solo induzidas pela poluição atmosférica, p. 137-164. In: M.I.M.S. LoPEs; M. KIRIZAWA \& M.M.R.F. Melo (Eds). Patrimônio da Reserva Biológica do Alto da Serra de Paranapiacaba. A antiga Estação Biológica do Alto da Serra. São Paulo, Instituto de Botânica, 720p.

Lips, K.R.; P.A. Burrowes; J.R. Mendelson \& G. Parra-Olea. 2005. Amphibian declines in Latin America: Widespread population declines, extinctions and impacts. Biotropica 37 (2): 163-165. doi: 10.1111/j.1744-7429.2005.00023.x

LuTz, B. 1958. Anfíbios novos e raros das Serras Costeiras do Brasil. Memórias do Instituto Oswaldo Cruz 56 (2): 373399. doi: 10.1590/S0074-02761958000200002

Magnusson, W.E.; A.P. Lima; J.M. Hero \& M.C. Araújo. 1999. The rise and fall of a population of Hyla boans: Reproduction in a Neotropical gladiator frog. Journal of Herpetology 33 (4): 647-656. doi: 10.2307/1565582

Marques, O.A.V. 2009. A fauna de répteis na região de Paranapiacaba, p. 605-620. In: M.I.M.S. Lopes; M. KIRIZAWA \& M.M.R.F. Melo (Eds). Patrimônio da Reserva Biológica do Alto da Serra de Paranapiacaba. A antiga Estação Biológica do Alto da Serra. São Paulo, Instituto de Botânica, 720p.

Marques, O.A.V.; A. Eterovic \& I. Sazima. 2004. Snakes of the Brazilian Atlantic Forest - An illustrated field guide for the Serra do Mar range. Ribeirão Preto, Holos Editora, 204p.
Marques, O.A.V.; D.N. Pereira; F.E. Barbo; V.J. Germano \& R.J. Sawaya. 2009. Os Répteis do Município de São Paulo: diversidade e ecologia da fauna pretérita e atual. Biota Neotropica 9 (2): 139-150. doi.org/10.1590/S1676-06032009000200014

Martins, I.A. 2010. Natural history of Holoaden luederwaldti (Amphibia: Strabomantidae: Holoadeninae) in southeastern of Brazil. Zoologia 27 (1): 40-46. doi: 10.1590/S198446702010000100007

Martins, I.A. \& H. Zaher. 2013. A new species of the highland frog genus Holoaden (Amphibia, Strabomantidae) from cloud forests of southeastern Brazil. Zootaxa 3599 (2): 178-188. doi: 10.11646/zootaxa.3599.2.4

Melo, M.M.R.F.; R.M. Moraes \& A.R. Santos. 2009. Publicações sobre a reserva Biológica do Alto da Serra de Paranapiacaba, p. 707-720. In: M.I.M.S. Lopes; M. KirizaWa \& M.M.R.F. Melo (Eds). Patrimônio da Reserva Biológica do Alto da Serra de Paranapiacaba. A antiga Estação Biológica do Alto da Serra. São Paulo, Instituto de Botânica, 720p.

MiKAN, J.C. 1820. Delectus florae et faunae Brasiliensis: jussu et auspiciis Francisci I, Austriae imperatoris investigatae. Vindobonae [Vienna]:Sumptubus auctoris, 1820 [25]: 43-44.

Miranda-Ribeiro, A. 1920. Algumas considerações sobre Holoaden luederwaldti e gêneros correlatos. Revista do Museu Paulista 12: 317-320.

Miranda-Ribeiro, A. 1926. Notas para servirem ao estudo dos gymnobatrachios (Anura) Brasileiros. Arquivos do Museu Nacional 27: 1-227.

Moraes, R.M.; A. Klumpp; C.M. Furlan; G. Klumpr; M. Domingos; M.C.S. Rinaldi \& I.F. Modesto. 2002. Tropical fruit trees as bioindicators of industrial air pollution in southeast Brazil. Environment International 28: 367-374. doi: 10.1016/ S0160-4120(02)00060-0

Moraes, R.M.; W.B.C. Delitti \& J.A.P.V. Moraes. 2003. Gas exchange, growth, and chemical parameters in a native Atlantic forest tree species in polluted areas of Cubatão, Brazil. Ecotoxicology and Environmental Safety 54: 339345. doi: 10.1016/S0147-6513(02)00067-2

Myers, N.; R.A. Mittermeier; C.G. Mittermeier; G.A.B. Da Fonseca $\&$ J. Kent. 2000. Biodiversity hotspots for conservation priorities. Nature 403: 853-845. doi: 10.1038/35002501

Oliveira, L.E.; R.M.C. Oliveira \& A.A. Giaretta. 2008. Ischnocnema hoehnei. Advertisement call. Herpetological Review 39 (2): 207-208.

Patto, C.E.G. \& M.R. Pie. 2001. Notes on the population dynamics of Hylodes asper in Southeastern Brazil (Anura: Leptodactylidae). Journal of Herpetology 35 (4): 684-686. doi: $10.2307 / 1565913$

Patto, C.E.G. \& M.R. PIE. 2006. Escape behaviour in the Neotropical frog Hylodes asper (Anura: Leptodactylidae). Acta Herpetologica 1 (2): 141-146.

Peters, J.A. 1960. The Snakes of the Subfamily Dipsadinae. Miscellaneous Publications Museum of Zoology University of Michigan 114: 1-228. 
PombaL JR, J.P. \& C.A.G Cruz. 1999. Redescrição de Eleutherodactylus bolbodactylus (Lutz, 1925) e a posição taxonômica de E. gehrti (Miranda-Ribeiro, 1926) (Anura, Leptodactylidae). Boletim do Museu Nacional, Nova Série, Zoologia 404: 1-10.

Pombal JR, J.P. \& M. Gordo. 2004. Anfíbios anuros da Juréia, p. 243-256. In: O.A.V. Marques \& W. Duleba (Eds). Estação Ecológica Juréia-Itatins. Ambiente físico, flora e fauna. Ribeirão Preto, Holos Editora, 384p.

Pombal JR, J.P.; I. SAZIMA \& C.F.B. HadDaD. 1994. Breeding behavior of the pumpkin toadlet, Brachycephalus ephippium (Brachycephalidae). Journal of Herpetology 28 (4): 516-519. doi: $10.2307 / 1564972$

Pombal Jr, J.P.; C.C. Siqueira; T.A. Dorigo; D. Vrcibradic \& C.F.D. Rocha. 2008. A third species of the rare frog genus Holoaden (Terrarana, Strabomantidae) from a montane rainforest area of southeastern Brazil. Zootaxa 1938: 61-68.

PMSA (Prefeitura do Município de Santo André). 2008. Atlas do Parque Natural Municipal Nascentes de Paranapiacaba: revelando o nosso Parque. São Paulo, Anablume Editora, $2^{\text {nd }}$ ed., 78p.

Ribeiro, M.C.; J.P. Metzger; A.C. Martensen; F.J. Ponzoni \& M.M. Hirota. 2009. The Brazilian Atlantic Forest: how much is left, and how is the remaining forest distributed? Implications for conservation. Biological Conservation 142: 1144-1156. doi: 10.1016/j.biocon.2009.02.021

Ribeiro, M.C.; A.C. Martensen; J.P. Metzger; M. Tabarelli; F. Scarano \& M. Fortin. 2011. The Brazilian Atlantic Forest: A Shrinking Biodiversity Hotspot, p. 405-434. In: F.E. ZACKOS \& J.C. HABEL (Eds). Biodiversity Hotspots. Distribution and Protection of Conservation Priority Areas. Berlin, Springer Verlag, XVII+546p.

Rocha, C.F.D.; M. Van Sluys; M.A.S. Alves; M.G. Bergallo \& D. Vrcibradic. 2001. Estimates of forest floor litter frog communities: A comparison of two methods. Austral Ecology 26 (1): 14-21.

Rocha, C.F.D.; D. Vrcibradic; M. Kiefer; C.M. Almeida-Gomes; N.T. Borges-Junior; P.C.F. Carneiro; R.V. Marra; P. Almeida-Santos; C.C. Siqueira; P. Goyannes-Araújo; C.G.A. Fernandes; E.C.N. RuBião \& M. VAN SLuYs. 2007. A survey of the leaf-litter frog assembly from an Atlantic forest area (Reserva Ecológica de Guapiaçu) in Rio de Janeiro State, Brazil, with an estimate of frog densities. Tropical Zoology 20 (1): 99-108.

Rodrigues, M.T. 2005. The Conservation of Brazilian Reptiles: Challenges for a Megadiverse Country. Conservation Biology 19 (3): 659-664. doi: 10.1111/j.1523-1739.2005.00690.x

Rossa-Feres, D.C.; M. Martins; O.A.V. Marques; I.A. Martins; R.J. SAWAYA \& C.F.B. Haddad. 2008. Herpetofauna, p. 83-94. In: R.R. Rodrigues; C.A. Joly; M.C.W. De Brito, A. Paese; J.P. Metzger; L. Casatti; M.A. Nalon; M. Menezes; N.M. Ivanauskas; V. Bolzani \& V.L.R. BONONI (Eds). Diretrizes para conservação e restauração da biodiversidade no estado de São Paulo. São Paulo, Imprensa Oficial do Estado de São Paulo, 248p.

Rossa-Feres, D.C.; R.J. Sawaya; J. Faivovich; J.G.R. Giovanelli; C.A. Brasileiro; L. Schiesari; J. AleXandrino \& C.F.B. Haddad. 2011.
Anfíbios do Estado de São Paulo, Brasil: conhecimento atual e perspectivas. Biota Neotropica 11 (1a): 1-19. Available online at: http://www.biotaneotropica.org.br/v11n1a/pt/ abstract?inventory+bn0041101a2011 [Accessed: April, 2014].

Santos-Pereira, M.; A. Candaten; D. Milani; F.B. Oliveira; J. GARDELIN \& C.F.D. Rocha. 2011. Seasonal variation in the leaf-litter frog community (Amphibia: Anura) from an Atlantic Forest Area in the Salto Morato Natural Reserve, southern Brazil. Zoologia 28 (6): 775-761. doi: 10.1590/ S1984-46702011000600008

Sazima, I. \& W.C.A. Bokermann. 1978. Cinco novas espécies de Leptodactylus do centro e sudeste brasileiros (Amphibia, Anura, Leptodactylidae). Revista Brasileira de Biologia 38 (4): 899-912.

Sawaya, R.J.; O.A.V. Marques \& M. Martins. 2008. Composition and natural history of a Cerrado snake assemblage at Itirapina, São Paulo State, southeastern Brazil. Biota Neotropica 8 (2): 127-148. doi: 10.1590/S1676-06032008000200015

ScotT JR., N.J. 1976. The abundance and diversity of the Herpetofaunas of tropical forest litter. Biotropica 8 (1): 4158. doi: $10.2307 / 2387818$

Silva, J.M.C. \& C.H.M. Casteletr. 2005. Estado da biodiversidade da Mata Atlântica brasileira, p. 43-59. In: C. GaLindo-LEAL \& I.G. CÂMARA (Eds). Mata Atlântica: biodiversidade, ameaças e perspectivas. São Paulo, Fundação SOS Mata Atlântica, 471p.

Siqueira, C.C.; D. VRcibradic \& C.F.D. Rocha. 2011. Anurans from two high-elevation areas of Atlantic Forest in the state of Rio de Janeiro, Brazil. Zoologia 28 (4): 457-464. doi: 10.1590/ S1984-46702011000400007

Stuart, S.N.; J.S. Chanson; N.A. Cox; B.E. Young; A.S.L. Rodrigues; D.L. Fischman \& R.W. Waller. 2004. Status and trends of amphibian declines and extinctions worldwide. Science 306: 1783-1786. doi: 10.1126/science. 1103538

Sugiyama, M.; R.P. Santos; L.S.J. Aguiar; M. Kirizawa \& E.L.M. CATHARINo. 2009. Cararcterização e mapeamento da vegetação, p. 107-117. In: M.I.M.S. Lopes; M. KIRIZAWA \& M.M.R.F. Melo (Eds). Patrimônio da Reserva Biológica do Alto da Serra de Paranapiacaba. A antiga Estação Biológica do Alto da Serra. São Paulo, Instituto de Botânica, 720p.

Thompson, G.G.; P.C. Withers; E.R. Pianka \& S.A. Thompson. 2003. Assessing biodiversity with species accumulation curves, inventories of small reptiles by pittrapping in Western Australia. Austral Ecology 28: 361-383. doi: 10.1046/j.14429993.2003.01295.x

Valdujo, P.H.; C.C. Nogueira; L. Baumgarten; F.H.G. Rodrigues; A. Eterovic; M.B. Ramo-Neto \& O.A.V. Marques. 2009. Squamate Reptiles from Parque Nacional das Emas and surroundings, Cerrado of Central Brazil. Check List 5 (3): 405-417.

Vasconcelos, T.S.; T.G. Santos; C.F.B. Haddad \& D.C. Rossa-FeRES. 2010. Climatic variables and altitude as predictors os anuran species richness and number of reproductive modes in Brazil. Journal of Tropical Ecology 26: 423-432. doi: $10.1017 /$ S0266467410000167 
Van Sluys, M.; D. Vrcibradic; M.A.S. Alves; H.G. Bergallo \& C.F.D. Rocha. 2007. Ecological parameters of the leaf-litter frog community of an Atlantic Rainforest area at Ilha Grande, Rio de Janeiro state, Brazil. Austral Ecology 32 (3): 254260. doi: 10.1111/j.1442-9993.2007.01682.x

Verdade, V.K.; M.T. Rodrigues \& D. Pavan. 2009. Anfíbios Anuros da Reserva Biológica de Paranapiacaba e entorno, p. 579604. In: M.I.M.S. Lopes; M. Kirizawa \& M.M.R.F. Melo (Eds. Patrimônio da Reserva Biológica do Alto da Serra de Paranapiacaba. A antiga Estação Biológica do Alto da Serra. São Paulo, Instituto de Botânica, 720p.

Verdade, V.K.; A.C. Carnaval; M.T. Rodrigues; L. Schiesari; D. Pavan \& J. Bertolucci. 2011. Decline of Amphibians in Brazil, p. 85-127. In: H. HeATWOLE; L. BarRIO-AMORÓs \& J. WiLKINSON (Eds). Amphibian Biology. Sydney, Surrey Beatty and Sons, vol. 9, 296p.

Verdade, V.K.; P.H. Valdujo; A.C. Carnaval; L. Schiesari; L.F. Toledo; T. MotT; G.V. Andrade; P.C. Eterovick; M. Menin; B.V.S.
Pimenta; C. Nogueira; C.S. Lisboa; C.D. Paula \& D.L. Silvano. 2012. A leap further: the Brazilian Amphibian Conservation Action Plan. Alytes 29 (1-4): 28-43.

Weygoldt, P. 1989. Changes in the composition of mountain stream frog communities in the Atlantic Mountains of Brazil: frogs as indicators of environmental deteriorations? Studies on Neotropical Fauna and Environment 243 (4): 249-255.

Zaher, H.; F.G. Grazziotin; J.E. Cadle; R.W. Murphy; J.C. MouraLeITE \& S.L. BonatTo. 2009. Molecular phylogeny of advanced snakes (Serpentes, Caenophidia) with an emphasis on South American Xenodontines: A revised classification and descriptions of new taxa. Papéis Avulsos de Zoologia 49 (11): 115-153. doi: 10.1590/S0031-10492009001100001

Zaher, H.; F.E. Barbo; P.S. Martínez; C. Nogueira; M.T. Rodrigues \& R.J. Sawaya. 2011. Reptiles from São Paulo State: current knowledge and perspectives. Biota Neotropica 11 (1a): 114.

Appendix 1. Historical records of anurans from Paranapiacaba, Santo André, São Paulo, gathered exclusively from the herpetological collections: Coleção Herpetológica do Museu de Zoologia da Universidade de São Paulo (MZUSP) and Museu de História Natural da Universidade Estadual de Campinas (ZUEC), São Paulo. Number of specimens refers to the total number of individuals deposited in collections from Paranapiacaba. None of those species were sampled during field surveys. Conservation status: Haddad (2008) (BR), Garcia et al. (2009a) (SP), and IUCN (2010) (EX: Extinct, CR: Critically Endangered, EN: Endangered VU: Vulnerable, NT: Near Threatened, DD: Data Deficient).

\begin{tabular}{|c|c|c|c|c|c|}
\hline \multirow{2}{*}{ Taxon } & \multirow{2}{*}{ Sampling period (year) } & \multirow{2}{*}{ Number of specimens } & \multicolumn{3}{|c|}{ Conservation status } \\
\hline & & & $B R$ & SP & IUCN \\
\hline Ischnocnema gehrti & 1926 & 1 & & & DD \\
\hline Cycloramphus dubius & $1901-1988$ & 29 & & & \\
\hline Cycloramphus semipalmatus & $1902-1973$ & 42 & & Vu & NT \\
\hline Bokermannohyla astartea & 1957-1990 & 11 & & & \\
\hline Dendropsophus nanus & 1952/1962/1966 & 103 & & & \\
\hline Dendropsopus sanborni & $1962 / 1981$ & 47 & & & \\
\hline Hypsiboas albopunctatus & 1895/1952/1963/1964/1990 & 9 & & & \\
\hline Hypsiboas cymbalum & 1963 & 3 & $\mathrm{CR}$ & $\mathrm{CR}$ & CR \\
\hline Phrynomedusa fimbriata & 1923 & 1 & EX & EX & EX \\
\hline Phyllomedusa burmeisteri & - & 2 & & & \\
\hline Phyllomedusa rohdei & $1962 / 1963 / 1965$ & 10 & & & \\
\hline Scinax alter & 1986 & 4 & & & \\
\hline Scinax berthae & $1962 / 1964 / 1965$ & 9 & & & \\
\hline Scinax squalirostris & 1962 & 10 & & & \\
\hline Crossodactylus dispar & 1969 & 4 & & EN & DD \\
\hline Hylodes phyllodes & 1963-1991 & 14 & & & \\
\hline Physalaemus maculiventris & $1952-1966$ & 13 & & & \\
\hline Physalaemus olfersii & $1896-1983$ & 13 & & & \\
\hline Leptodactylus flavopictus & 1951-1971 & 10 & & & \\
\hline Leptodactylus furnarius & 1899/1903/1963 & 6 & & & \\
\hline
\end{tabular}

Submitted: 30.VIII.2013; Accepted: 31.I.2014. Editorial responsibility: Ana Lúcia Prudente 